\title{
Titulação escolar, condição de "elite" e posição social
}

\author{
Odaci Luiz Coradini
}

Universidade Federal do Rio Grande do Sul, Instituto de Filosofia e Ciências Humanas

\section{Introdução}

O objetivo principal do presente texto consiste na apresentação de alguns resultados do exame das relações entre titulação universitária, ocupação profissional e posição social, particularmente no que tange a categorias socialmente dominantes no Brasil das últimas décadas. Utilizando como fonte de dados empíricos os microdados dos censos de 1970 a 2000, são confrontados os títulos universitários com os destinos ocupacionais e com o rendimento do trabalho principal. Conforme a hipótese geral perseguida, como os usos sociais dessa titulação universitária se inscrevem numa diversidade de mercados e de relações diferenciadas com a estrutura de poder, por um lado ocorre o crescimento da proporção daqueles que têm ocupação de "elite", ou de gestão e comando, que abrange quase todos os títulos universitários, por outro a forte polivalência nos usos da titulação universitária resulta também na grande quantidade dos que exercem alguma ocupação com rendimento inferior ao da categoria correspondente à respectiva titulação escolar.
Para uma das principais elaborações conceituais que têm como objeto as relações entre o mercado escolar e o mercado de trabalho, de Bourdieu e Boltanski (1975), os descompassos entre esses mercados resultam da autonomia relativa do campo escolar ante o campo econômico e das consequentes diferenças de interesses e de temporalidades nas eventuais mudanças. Isso cria a possibilidade de diferenças entre as "propriedades pessoais, como o diploma", que são adquiridas "de uma só vez e acompanham o indivíduo durante toda a vida" e "as características do cargo, cuja mudança depende da economia" (idem, p. 98-103). Em contrapartida, além das estratégias e lutas individuais e coletivas pela valorização da titulação escolar ou dos cargos, existem possibilidades variadas de reconversão social e profissional. Nesses processos de reconversão, mais generalizados nas situações de inflação de títulos e crise de mercado, os setores e profissões de representação, que são mais indeterminadas, contariam com mais possibilidades (Bourdieu, 1978). No entanto, nas condições estudadas, a forte polivalência nos usos sociais e profissionais abrange quase todos os títulos 
escolares, não se restringindo, portanto, àqueles cujas profissões correspondentes são mais indeterminadas.

Em trabalhos posteriores, particularmente naquele dedicado ao estudo das relações entre escolarização e "elites" (Bourdieu, 1989), são propostos alguns instrumentos analíticos que podem sinalizar avanços significativos nesse sentido. Trata-se mais diretamente da proposição conforme a qual, na divisão das instituições universitárias, um dos polos corresponde ao maior grau de autonomia e capacidade de imposição de critérios técnicos e éticos especificamente escolares e outro às origens e qualidades sociais e à estrutura de capital herdada dos alunos (idem, p. 213, 1984), porém, apesar da relativa autonomia do campo escolar (pelo menos para o caso da França), os usos sociais da titulação escolar estão subordinados a estratégias de reprodução que remetem a outras esferas e instituições. Dentre essas esferas e instituições, estão o grupo familiar, a organização empresarial, as burocracias públicas ou privadas, as corporações em geral e, particularmente no que tange aos grupos socialmente dominantes ou à "elite", o capital de relações sociais e as afinidades de estilos de vida (Bourdieu, 1989, p. 450-481). Ainda que, nessa perspectiva teórica, o capital escolar esteja associado a determinada "competência técnica", sua realização social depende da "competência social" e, portanto, da modalidade de inserção de seu portador em diferentes mercados específicos. Em contrapartida, particularmente no que se refere ao mercado escolar e dos serviços de algumas profissões, trata-se de um "mercado regulado", cuja configuração depende do confronto de interesses investidos nos organismos públicos e da representação dos interesses organizados envolvidos. Nessas condições, as chances de um produto ou serviço ser controlado pelo Estado num grau maior depende da "opinião mobilizada", no sentido de que seja indispensável e do grau de fragilidade do mercado (Bourdieu \& Christin, 1990, p. 66). Portanto, as condições particulares de cada caso dependem das respectivas configurações de interesses em confronto.

Desse modo, além dos respectivos mercados, são introduzidas como condicionantes dos usos sociais da titulação escolar as relações com posições socialmente dominantes, porém, mais que algum grupo predefinido e delimitado substantivamente, o problema analítico consiste nas posições ou no "campo de poder", cuja "estrutura se define pelo estado das relações de força entre espécies de capital" (Bourdieu, 1989, p. 373375). ${ }^{1}$ No que tange especificamente às relações entre posição social e campo escolar, é necessário considerar ainda os efeitos da existência (ou não) de algum setor específico dirigido explicitamente à formação de elites. Casos como o da França têm como uma das principais características manter um setor de ensino (as "grandes escolas") explicitamente voltado para a formação de "elites" (que serve, inclusive, de base empírica para as principais formulações de Bourdieu (1984, 1989; Bourdieu \& Saint Martin, 1987). Nesse caso, a "competência técnica" específica adquire contornos próprios que, embora de difícil definição, se acabam manifestando numa maneira de ser, mas não deixa de constituir uma "competência", associada a determinada escolarização, embora tendo o capital cultural de origem e o capital de relações como condição de realização. Desse modo, tanto a relativa autonomia do campo escolar e sua bipolarização entre as "grandes" e as "pequenas" escolas, como entre o polo mais associado ao capital escolar (científico ou cultural) e suas regras e ética próprias e, em contrapartida, às "escolas de poder" (Bourdieu, 1989, p. 213; Bourdieu \& Saint Martin, 1987), são o resultado dessa configuração específica. No que se refere à escolarização de "elites", além de um conjunto de instituições especificamente dirigido a isso, suas relações com o Estado e uma concepção carismática de autoridade, com um ensino centrado no "julgamento total das pessoas" (Garrigou, 2001, p. 234-235), isso resultou na tensão entre a pretensão de formação de "elites" gestoras do Estado

${ }^{1}$ Para uma discussão mais geral das dificuldades em tomar as “elites" ou grupos dirigentes como objeto de estudo e o substantivismo e o elitismo como alguns dos principais obstáculos, ver Coradini (2008). Para uma descrição minuciosa da evolução dos usos sociais da chamada "teoria das elites", ver Grynszpan (1996). 
e o modelo anglo-saxão das business schools. Ocorre que, no caso em pauta, ao se tratar de uma configuração histórica "periférica", o problema das relações da titulação escolar com a posição social e aquele do processo de profissionalização têm outras bases. Se, por um lado, não existe algum setor do ensino superior explicitamente dirigido à formação de elites, por outro, como os dados apresentados adiante indicam, boa parte dos portadores de títulos universitários, em diferentes áreas do conhecimento, mantêm posições homólogas ou semelhantes.

Isso vai ao encontro dos resultados do estudo de Karady (1991) sobre as relações entre os estudos jurídicos e a reprodução das elites húngaras (que, no que tange ao confronto com as condições estudadas no presente trabalho, tem a vantagem heurística de também se tratar de uma configuração periférica). Para o autor (idem, p. 109), a razão das intensas relações entre descendentes da nobreza e os estudos jurídicos decorre das afinidades entre as carreiras jurídicas e as atividades públicas. O direito constitui uma "competência genérica" afim a esse tipo de atividade. Além disso, no período mais recente, diante da inflação de títulos escolares, o diploma em direito conta com a vantagem de não conduzir exclusivamente a um determinado mercado (como a medicina), permitindo assim reconversões e escolhas profissionais alternativas conforme cada conjuntura. Mas, além dessa polivalência socioprofissional da formação jurídica, sua expansão estaria vinculada também à "herança profissional" através da transmissão familiar de parte das competências e do capital de relações sociais (idem, p. 120). Essas proposições vão ao encontro das constatações de Dezalay e Garth quanto aos usos sociais do direito em sociedades periféricas (América Latina, Filipinas), particularmente devido à posição dos juristas como mediadores no sistema de patronagem estabelecido entre o poder local e as elites internacionais (Dezalay \& Garth, 2008, p. 50; Dezalay \& Garth, 2002; Dezalay, 2004), porém, no caso em pauta, se por um lado fica evidente que a polivalência nos usos sociais e profissionais da titulação escolar tem nas ocupações de "elite" ou de comando e gestão um de seus fundamentos, por outro isso está muito longe de se restringir ao direito. Até porque os portadores de títulos em direito, de graduação, de mestrado ou doutorado, constituem um dos poucos casos de evolução no sentido da maior correspondência entre o título escolar e a ocupação.

Essas perspectivas quanto aos usos sociais da titulação escolar e suas relações com posições sociais dominantes ou de "elite" confluem com algumas proposições básicas do credencialismo. Uma dessas confluências entre perspectivas baseadas no credencialismo e proposições de Bourdieu, como destacado inclusive por Brown (2001, p. 27-28) consiste, em primeiro lugar, na importância central da cultura geral e do caráter simbólico das credenciais no recrutamento de "elites". A segunda consequência importante é a ênfase na diversidade de formas que as credenciais podem tomar nas burocracias privadas ou públicas e no estabelecimento de prerrogativas e regras profissionais. $^{2}$

Quanto aos problemas relativos à definição de mercado, a proposição de "mercados múltiplos", visando a incorporar os "fatores econômicos, culturais e estruturais" (Zelizer, 1992, p. 10), ${ }^{3}$ pode constituir um instrumento analítico importante. Além de mercados como aquele de "adoção de crianças", esse esforço na definição das bases de mercados específicos resultou também em estudos de mercados de trabalho particulares, como aquele em que operam os "caçadores de talento" para cargos de direção de empresas. Mais que outros mercados de trabalho, tratar-se-ia de um "mercado particular", em que, além da competência

${ }^{2}$ Para uma discussão mais geral sobre as relações entre titulação escolar e prerrogativas e credenciais profissionais e sociais, ver particularmente Collins (1979), Brown (2001) e Weber (1984, p. 242-248). Para uma perspectiva distinta, opondo normativamente mercado e credencialismo na interpretação da evolução do ensino brasileiro e apostando na evolução positiva do primeiro, consultar Schwartzman (2000).

${ }^{3}$ Para um balanço mais geral desses esforços de redefinição do conceito de mercado, com perspectiva própria, consultar Fligstein (1996). 
diretamente profissional, é a personalidade dos candidatos que é avaliada após uma seleção mais geral. Além das empresas demandantes, os próprios escritórios de "caçadores de talento" contribuem para definir o mercado de "quadros dirigentes" (Gautie, Godechot $\&$ Sorignet, 2005). ${ }^{4}$

A noção de "profissão" deve ser considerada em relação a outras noções, particularmente aquela de "ocupação" e aos problemas analíticos vinculados a elas. Posições teóricas e conceituais, como a chamada sociologia das profissões, têm suscitado tanto adesão como repulsa, além de diferentes usos e reapropriações. Não caberia entrar aqui nesse tipo de discussão, mas é necessário destacar alguns aspectos para melhor compreensão da perspectiva adotada. O primeiro desses aspectos é que, inclusive para alguns dos principais formuladores e expoentes da sociologia das profissões, a "profissão" ou o "profissionalismo" consiste em algo específico e característico de condições históricas e sociais particulares, associadas às sociedades anglosaxônicas. Consequentemente, além dos problemas conceituais, seus próprios formuladores, como é o caso de Freidson (1998, p. 48), destacam a necessidade de abandonar "a tentativa de tratar a profissão como um conceito genérico" para considerá-la como "ocupações particulares" que ocorrem "numa quantidade limitada de sociedades" em períodos históricos específicos. Além disso, sua ocorrência não elimina os problemas relativos às suas relações com o mercado e com o controle e a regulamentação estatal, com o controle empresarial e burocrático do trabalho e com as demais formas de organização do trabalho. Em síntese, aquilo que é definido como "profissão" consiste em algo histórica e socialmente delimitado e restrito, diferentemente da "ocupação". Sendo assim, não caberia discutir os limites e as controvérsias relativas aos significados da "profissionalização", inclusive porque estão assentadas em diferentes bases teóricas e conceituais, além de condições históricas e sociais

${ }^{4}$ Para um estudo semelhante no recrutamento de dirigentes de empresas no Brasil, centrado na questão da valorização do diploma universitário, ver Alves e Almeida (2009). particulares, distintas daquelas do caso em pauta. Isso não exclui, no entanto, uma posição específica relativamente a esse tipo de problema, que consiste, em primeiro lugar, em tomar a "profissão" como um fenômeno específico, com amplitude variada e interdependente de outros princípios e recursos que estão na base da divisão social do trabalho, da estrutura de poder e das "ocupações". Desse modo, não se trata de negar os eventuais processos mais gerais de "profissionalização", mas considerá-los algo que deve ser tomado em suas condições e configurações particulares e concretas. Isso implica considerar os eventuais processos de "profissionalização" sem excluir suas relações com determinados campos ou esferas e respectivos recursos sociais, sejam aqueles associados ao grupo familiar, às relações com as políticas de Estado e com diferentes mercados, como já indicado para o caso dos juristas no exemplo da França (Boigeol \& Dezalay, 1997). Isso vai ao encontro da proposição de tomar a "profissão" como "mercado fechado", ou seja, como "monopolização de um determinado segmento de mercado de trabalho visando controlar a incerteza da relação salarial ou mercantil". Assim, se "profissões" podem ser "distinguidas como uma espécie do gênero 'mercado fechado', é pelo peso específico - e não pela natureza - de diversos componentes do jogo social em que se investem arranjos e desarranjos das identidades e das regras que protegem suas fronteiras" (Paradeise, 1988, p. 12, 20). Assim, apesar de situações as mais diferenciadas quanto a processos e a graus de profissionalização e de determinação de prerrogativas profissionais, isso não pode ser diretamente atribuído ao título ou à formação escolar nem ao tipo de atividade.

Em todo caso, categorias como "profissão" ou “ocupação" não estão presentes apenas como problemas de definição conceitual, mas também nos esquemas de classificação estatística. Como já destacado para outros contextos, as categorias estatísticas - censitárias ou de outro tipo - são o produto da aplicação de esquemas de classificação cujos princípios que os fundamentam são mutáveis e diversos (Merllié, 1983; Zarca, 1993). A condição primeira para sua utilização 
na análise sociológica é o domínio dos esquemas de classificação e os interesses em jogo na coleta, armazenamento e difusão das informações estatísticas. No caso em pauta, como é indicado adiante, uma das principais limitações das categorias censitárias decorre do fato de que estão excessivamente centradas na divisão técnica do trabalho, em detrimento da posição social que as categorias podem representar. Além disso, acrescem-se os problemas decorrentes das relações dessas categorias estatísticas com aquelas do universo escolar, como a própria titulação, que também são o resultado de determinados processos de elaboração e imposição de esquemas de classificação, além de outras matrizes de classificação com as quais as categorias estatísticas podem interagir, como aquelas do espaço sindical.

Conforme já mencionado, a hipótese mais geral perseguida é a de que, nas condições estudadas, um dos principais responsáveis pela polivalência nos usos da titulação escolar é a ocupação de posição socialmente dominante, ou de "elite", como meio de acesso ou de legitimação de posições de comando e gestão, de boa parte dos portadores dessa titulação. Em contrapartida, outro dos principais responsáveis pela polivalência ocupacional são as condições sociais e profissionais desfavoráveis de outra boa parte dos portadores de titulação universitária, cuja ocupação e rendimento econômico estão abaixo da média dos que exercem ocupações conforme a definição formal do curso concluído. $\mathrm{Na}$ passagem da titulação escolar para a ocupação efetiva se interpõe uma multiplicidade de mercados que incluem aqueles de postos de comando e gestão de empresas privadas ou públicas, de serviços profissionais com base em diferentes estruturas organizacionais e aqueles mercados mais fortemente dirigidos politicamente, como o magistério de ensino fundamental e médio e os serviços burocráticos subalternos.

\section{O material empírico utilizado e as principais constatações}

Como já foi mencionado, as principais fontes de material empírico utilizadas consistem nos microdados dos censos de 1970 a 2000 do IBGE. Apesar de sua generalidade, esse material fornece alguns indicadores relevantes para o exame das relações entre titulação escolar, ocupação profissional e rendimentos. Dentre as variáveis mais diretamente utilizadas, destacam-se o tipo do último curso concluído, as ocupações profissionais e o rendimento econômico.

Até onde alcançam as informações, os censos constituem a única fonte do IBGE que dispõem a quantidade de educação formal através do título obtido no último curso concluído e não apenas pelo seu grau ou então pela quantidade de anos de estudo. Isso não exclui determinados problemas, particularmente no que tange às alterações das categorias escolares no decorrer do período analisado e os agrupamentos de diferentes títulos. De todos os censos disponíveis em microdados, o de 2000 é o mais completo relativamente a esse ponto. Além da categoria formada pelos sem curso superior, nesse censo foram incluídos 58 cursos de graduação, de mestrado ou doutorado ou ainda agrupamentos de diversos cursos de graduação ou de mestrado ou de doutorado. No caso dos agrupamentos (os “outros”), o único critério explícito é o pertencimento a uma das cinco áreas de conhecimento utilizadas como critério de classificação dos cursos. ${ }^{5}$ As centenas de categorias ocupacionais originais foram reduzidas em diferentes agrupamentos; o mais utilizado contém 37 categorias. O principal critério de agrupamento, nesse caso, tem como base as relações dessas categorias com a posição social e, particularmente, as associações com o rendimento econômico e a titulação escolar ou, ainda, com o total de anos de estudo. ${ }^{6}$ Visto que, para os censos foram mantidas as antigas classificações profissionais após as alterações no decorrer do período, é possível acompanhar a evolução numa série temporal significativa.

\footnotetext{
${ }^{5}$ Para mais detalhes, ver IBGE (2003, Arquivos Auxiliares/ Cursos Superiores-Estrutura).

${ }^{6}$ Originalmente, o objeto da pesquisa que deu origem inclusive ao presente texto são os professores de ensino superior como categoria social. Essa pesquisa continua em desenvolvimento, com apoio do INEP/CAPES/Observatório da Educação (edital n. 001/2006).
} 
Ao confrontar o título escolar mais alto obtido com a ocupação declarada no censo, no período de 1979 a 2000, a primeira constatação mais geral é a relativamente baixa proporção, embora variável, daqueles em que há correspondência entre ambos (tomando as ocupações em 37 agrupamentos). ${ }^{7}$ Apenas alguns poucos títulos de graduação, de mestrado ou doutorado - em medicina, odontologia, direito e os cursos militares - superaram os $60 \%$ em 2000 . Além disso, embora para alguns títulos escolares com menor grau de determinação da profissão, especialmente os de licenciatura, a ocupação tomada como correspondente não seja exclusiva, mais da metade dos títulos tem menos da terça parte de seus portadores na respectiva ocupação. Para a maior parte dos casos, a proporção daqueles cujo título escolar coincide com o respectivo agrupamento ocupacional situa-se entre $30 \%$ e $60 \%$, apesar da relativamente forte dispersão. A segunda constatação mais geral é a de que essa proporção daqueles em que há correspondência entre as prescrições formais ou a disciplina do título escolar universitário, de graduação ou de mestrado ou doutorado, e a ocupação declarada tende a diminuir ou então a se manter estável, mas em geral não aumentou no período considerado.

A terceira constatação geral é de que, juntamente com a tendência de aumento da dispersão dos portadores de um determinado título num espectro maior de ocupações, em algumas categorias tende a haver maior crescimento. Dentre essas categorias, destacamse três que podem ser consideradas componentes de grupos dirigentes ou "elite": os agrupamentos dos empregadores e proprietários no geral, dos gerentes de empresas privadas e diretores e chefes na administração pública. Portanto, trata-se de categorias socialmente dominantes, uma das quais se caracteriza pela propriedade de capital econômico, a segunda pela

${ }^{7}$ Com a utilização de outros critérios e com o objetivo de estudar o retorno econômico dos investimentos em educação, a grande quantidade dos que não exercem a "função típica" da titulação, para o período de 1982 a 1997, também foi constatada por Fernandez e Narita (2001). gestão do capital econômico e, por fim, uma terceira pela detenção de algum tipo de capital político. Para alguns títulos universitários, particularmente aqueles de nível de mestrado ou de doutorado, outra categoria específica de "elite" que tende a aumentar no decorrer do período, em condições específicas e de modo variável, é a dos professores de ensino superior. Uma quarta constatação geral é o forte aumento da proporção daqueles com ocupações subalternas, que tendem a se concentrar ainda mais entre os que têm titulação escolar com menor valor econômico (como os de licenciatura) ou então em cursos com maior heterogeneidade e, portanto, polivalência (como os de direito e de administração, dentre outros).

Sendo assim, somente os portadores de alguns poucos títulos universitários têm proporção com forte predominância daqueles cujo destino profissional mantém relações formalmente mais diretas com as prescrições do curso. Dentre esses, destacam-se os que têm graduação em odontologia, medicina e enfermagem. A situação dos graduados em farmácia, apesar da proximidade como área de conhecimento, é muito diferente, variando entre menos de uma quinta parte acerca da metade. Em contrapartida, os graduados em engenharia civil têm proporção de pouco mais da metade, que tende a diminuir no período. Os graduados em direito mantêm proporção de correspondência ainda menor, mas, como já mencionado, há tendência de crescimento, tanto para os que têm apenas graduação como para os com mestrado ou doutorado. Os graduados em arquitetura e urbanismo têm proporção um pouco mais alta, de pouco mais da metade, mas também com tendência de diminuição; e os graduados em teologia também têm decréscimo, de modo semelhante aos graduados em medicina veterinária. Por fim, os graduados em cursos militares mantêm a proporção de correspondência entre o título escolar e o grupo ocupacional um tanto mais alto, mas também com decréscimo e muitas oscilações no período. Como parece evidente, nos casos de proporção mais alta de correspondência entre o título e a ocupação, geralmente se trata de profissões com mercado mais delimitado e com prerrogativas profissionais mais esta- 
belecidas. Ainda assim, com algumas exceções, perto da metade dos portadores da maior parte dos títulos não exerce alguma ocupação formalmente enquadrada na respectiva categoria ocupacional.

Além disso, dentre a grande quantidade de portadores de títulos com baixa correspondência com a ocupação declarada, destacam-se os graduados em agronomia, em outros cursos de ciências agrárias - que não agronomia ou medicina veterinária -, psicologia, engenharia elétrica, engenharia mecânica, engenharia química, outros cursos de graduação em engenharia, ciências da computação, estatística, geologia, ciências contábeis e atuariais, ciências econômicas, comunicação social e, por fim, os cursos de licenciatura em geral. Para estes últimos, na maior parte dos casos em torno de um terço dos respectivos portadores de titulação, embora com muitas variações para baixo, é constituído de professores de ensino de $2^{\circ}$ grau e uma parte menor de ensino de $1^{\circ}$ grau.

Ao considerar separadamente aqueles com título de mestrado ou doutorado, a proporção de correspondência entre a "profissão" à qual o respectivo curso universitário dirige-se (médico, advogado) e a ocupação efetiva declarada diminui ainda mais. Nesse caso, a ocupação daqueles com título de mestrado ou de doutorado que mais aumenta é a de professor de ensino superior. Assim, aqueles com mestrado ou doutorado em ciências agrárias mantêm a proporção de apenas cerca da terça parte como agrônomos. Algo semelhante ocorre com aqueles com mestrado ou doutorado em engenharia e os que têm outros títulos de mestrado ou doutorado em ciências exatas e tecnológicas, que não os de engenharia. A exemplo dos títulos de graduação, as principais exceções com aqueles com mestrado ou doutorado ocorrem com os de medicina e direito, com alta proporção de correspondência entre o título e a ocupação, embora em grau bem menor do que os apenas graduados.

Conforme mencionado, como hipótese geral de trabalho a polivalência nos usos sociais da titulação escolar está associada também à ocupação de posições socialmente dominantes, através do exercício de cargos de comando ou de gestão por parte de seus portadores.
No extremo oposto, essa polivalência ocupacional está associada a condições sociais, escolares e profissionais mais desfavoráveis, que abrangem boa parte dos portadores de titulação universitária com rendimento econômico abaixo da média daqueles que exercem ocupações conforme as prescrições do título.

Embora essas diferenças nos usos sociais da titulação escolar, particularmente no que tange aos rendimentos econômicos, possam parecer um convite ao confronto com trabalhos de economistas, isso está fora dos limites do presente texto por diversas razões. A primeira delas é que, devido à complexidade de condições sociais que podem ter efeitos nas relações entre a quantidade de escolarização e as condições individuais de existência e aos requerimentos e limites quanto às fontes necessárias, esse problema constitui o objeto de outro trabalho em desenvolvimento. Especificamente no que tange aos resultados dos investimentos em educação em âmbito internacional, nas últimas décadas, como é sabido, tem-se expandido a quantidade de trabalhos realizados por economistas e por sociólogos sobre o tema. Embora geralmente as contribuições vão no sentido da constatação e ênfase de relações positivas entre investimento em educação e rendimento econômico, há uma série de dificuldades conceituais e técnicas nesse tipo de estudo, e os resultados são tidos como ainda limitados e muito contraditórios (para uma balanço geral, ver particularmente Baudelot et al., 2004). De modo quase restrito à economia, esse tipo de estudo teve alguma expansão inclusive no Brasil (entre outros, Veloso et al., 2009; Fernandez \& Narita, 2001; Barros \& Mendonça, 1996). Evidentemente, de uma perspectiva não restrita à economia e mais especificamente à chamada teoria do capital humano, poderia ser formulada uma série de críticas a esse tipo de trabalho. Isso inclui seu caráter abstrato e genérico, seu deducionismo, os pressupostos de uma determinada racionalidade utilitarista universalizada, sua unidimensionalidade e assim por diante, porém o confronto com os limites de esquemas como aqueles dos economistas adeptos de teorias como a do capital humano ou de outras não teria muito sentido. Isso decorre inclusive do fato de que os limites dos 
respectivos objetos são o resultado também das próprias perspectivas teóricas e preocupações práticas, que são relativamente autônomas.

Como já mencionado, algumas categorias profissionais baseadas nas classificações censitárias podem ser tomadas em seu sentido de atividade ou ocupação (ou cargo) ou enquanto indicador de condição ou de posição social, com base em diferentes recursos. No que tange às posições socialmente dominantes, esse é o caso, particularmente, do agrupamento de ocupações sob a etiqueta de empregadores e proprietários em geral, cujo recurso principal está, evidentemente, na posse de determinado montante de capital econômico. Um segundo agrupamento de ocupações que se destaca nesse sentido é o dos administradores e gerentes de empresas privadas, que, se por um lado pode estar fortemente associado à categoria dos empregadores e proprietários em geral, por outro também pode conter características próprias, inclusive porque tem nas atividades ou ocupações relativas a gestão e controle sua principal razão de ser, além das diferenças quanto ao rendimento, como indicado adiante. Por fim, um terceiro agrupamento socialmente dominante ou de "elite" que se destaca é aquele dos diretores e chefes na administração pública, cujo principal recurso tem como base algum tipo de capital político. Como no Brasil, quantitativamente, a quase totalidade dos cargos com poder de decisão "política" (com exceção daqueles com base em processos eleitorais) tem como critério de recrutamento a "indicação" ou cooptação, é de supor que sua principal base esteja no capital político associado a algum tipo de engajamento ou em outros critérios de cooptação e "indicação", cujas particularidades, obviamente, os dados utilizados não têm condições de apreender. Em todo caso, apesar das evidentes fortes clivagens e diferenças internas nesses agrupamentos ocupacionais e na comparação entre si, eles podem ser tomados como representativos das categorias com posição social mais alta, em suas relações com os usos da titulação escolar.

Como os dados expostos a seguir evidenciam, há uma tendência geral, embora não unívoca, da associação entre titulação universitária e posição socialmente dominante e de comando administrativo e político, que abrange crescentemente a maior parte dos títulos, com relativa independência do conteúdo da respectiva disciplina ou área de conhecimento. Dito de outro modo, na diversidade de mercados em que esses títulos escolares se inscrevem, um dos polos é representado por seus usos (que certamente também são diversificados) na perspectiva de posições social e politicamente dominantes.

Ao tomar conjuntamente esses três agrupamentos ocupacionais social e politicamente dominantes, como seria de esperar, o extremo do polo mais diretamente associado é representado por categorias como aquelas com mestrado ou doutorado em administração, em outros cursos de engenharia - que não engenharia civil, mecânica, elétrica e eletrônica e química e industrial-, com graduação em administração, propaganda e marketing e ciências econômicas, dentre outros. Em síntese, no geral os formados em cursos das engenharias ou das chamadas ciências sociais aplicadas têm entre a quinta parte à quase metade como componente de algum dos três segmentos de "elite" em pauta.

No que tange aos formados em administração ou em economia, como se trata de cursos dirigidos à formação de gestores, a grande quantidade de administradores e gerentes de empresas e organizações não poderia ser definida como incongruência relativamente ao título, mas o mesmo não poderia ser concluído a partir da grande quantidade dos classificados como empregadores e proprietários em geral ou como diretores e chefes na administração pública. Coisa semelhante se aplica aos portadores de outros títulos universitários, como os das engenharias.

Além disso, ao considerar o polo de menor proporção nessas três categorias de "elite", uma primeira constatação que se depreende é a pequena quantidade de títulos universitários em que não ocorre alguma proporção significativa daqueles classificados nelas. Além daqueles sem curso superior, sobressaem-se apenas os portadores de alguns títulos universitários da área médica, como os graduados em odontologia, em enfermagem e com graduação ou mestrado ou doutorado em medicina, além de outros cursos na área 
de ciências humanas ou com mercado profissional mais circunscrito, como os graduados em teologia, com mestrado ou doutorado em letras e artes, com cursos militares de nível superior, com graduação em biblioteconomia, em letras, com mestrado ou doutorado em direito e em alguns outros cursos de licenciatura. Todos os demais títulos têm no mínimo a décima parte em ocupações profissionais em uma das categorias de "elite" (como definidas antes). Como fica evidente, os poucos casos de menor proporção no pertencimento a essas categorias consistem em profissões mais estabelecidas e exclusivas ou então em cursos associados a condições sociais mais baixas, como os de licenciatura, o que pode ser constatado inclusive pelo montante de rendimento, conforme indicado adiante. Isso, no entanto, não exclui a participação significativa, por exemplo, de mais da décima parte, nessas categorias de "elite", dos portadores de títulos de uma série de cursos de licenciatura ou formalmente dirigidos para a formação de professores de ensino de $1^{\circ}$ ou $2^{\circ}$ grau, como pedagogia, filosofia, ciências, estudos sociais e química, dentre outros. Isso também não exclui alguns títulos escolares que remetem a profissões mais estabelecidas e exclusivas, mas cujos portadores podem ser, simultaneamente, agentes em outros mercados, como é o caso dos graduados em estatística, com quase a quinta parte como integrante de alguma das três categorias de "elite", em geologia, em agronomia, dentre outros.

Outro conjunto de constatações que se depreende é relativo às tendências quanto à evolução, no período analisado, dessas proporções de portadores de titulação universitária -em categorias ocupacionais de "elite". O primeiro ponto a destacar é que não ocorre alguma tendência de formação de algum tipo de curso especializado na formação de "elites". Apesar da forte participação de cursos como os de administração e de economia, e da falta de precisão na comparação das classificações escolares no período em pauta, não ocorre algum acréscimo significativo nesse sentido. Assim, aqueles com mestrado ou doutorado em administração tiveram uma tendência de diminuição nas três categorias. Algo semelhante ocorre com os graduados em administração. Os graduados em ciências econômicas mantêm-se no mesmo patamar. Simultaneamente, surgiram novos cursos e títulos próximos, como a graduação em propaganda e marketing, com mais da terça parte dos titulados como componentes da "elite". No que tange às engenharias, mesmo para os cursos mais tradicionais, como o de engenharia civil, ocorre a manutenção da proporção de componentes da "elite" em torno da quinta parte; em contrapartida, surgem novos cursos de engenharia com proporções mais altas. Esse é o caso, dentre outros, dos graduados em engenharia mecânica, com cerca da terça parte, da engenharia química e industrial, da engenharia elétrica e, particularmente, dos outros cursos de engenharia - que não engenharia civil, mecânica, elétrica e eletrônica e química e industrial - também com mais da terça parte com ocupação em alguma das categorias de "elite". Algo semelhante ocorre com os graduados em agronomia, cuja proporção de componentes da "elite" se mantém relativamente estável, mas, enquanto isso, surgiram outros cursos próximos, conforme os classificados como outros de ciências agrárias - que não agronomia e medicina veterinária - com proporção de componentes de alguma das categorias de "elite" muito mais elevada. Um processo semelhante ocorre com várias outras áreas, com a diversificação e oferta de novos títulos, como na área de jornalismo e comunicação social, com alta proporção de componentes da "elite" e, inclusive, na área de letras e artes, com outros cursos de graduação em letras e artes, com quase a quinta parte dos portadores do respectivo título como administradores e gerentes de empresas privadas.

Como já mencionado, além dos empregadores e proprietários em geral, dos diretores e chefes na administração pública e dos administradores e gerentes de empresas privadas, considerando-se as últimas décadas, outro mercado socialmente dominante para portadores de titulação escolar mais alta é constituído pelo ensino superior, porém, apesar de sua relativamente forte expansão em termos absolutos, constitui o destino ocupacional numa proporção importante apenas para alguns títulos mais altos. Trata-se, particularmente, de mestres ou doutores e, dentre estes, de 
algumas áreas/disciplinas de menor aplicação prática. É o caso, particularmente, dos mestres ou doutores em outros cursos das ciências exatas e tecnológicas que não as engenharias $(32,66 \%$ como professores de ensino superior em 2000), em ciências agrárias (30,11\%), em ciências humanas e sociais que não as aplicadas (26,33\%), em letras e artes $(25,71 \%)$, em ciências biológicas e da saúde que não as aplicadas $(23,83 \%)$ e em pedagogia (19\%), porém, mesmo entre os que têm mestrado ou doutorado, no caso de alguns cursos de cunho mais aplicado, como administração $(8,59 \%)$ e direito $(6,31 \%)$, a proporção de professores de ensino superior é relativamente pequena. Quanto aos portadores de títulos de graduação, a proporção de professores de ensino superior geralmente é muito baixa, nunca atingindo a décima parte e para cerca da metade dos casos, não chegando a 1\%. Em muitos casos há a tendência de diminuição dessa proporção no decorrer do período.

Mas, além daqueles cujo destino ocupacional corresponde às prescrições do título escolar e daqueles nas ocupações socialmente mais dominantes, no geral ocorre altíssima dispersão quanto ao destino ocupacional. Praticamente a totalidade dos títulos escolares em análise tem boa parte, embora variável para cada caso, de portadores cujo destino ocupacional abrange quase todos os 37 agrupamentos profissionais utilizados para classificação, ou seja, trata-se de diversos mercados para cada título e, em boa parte dos casos, equivale a ocupações social ou pelo menos economicamente inferiores à posição da respectiva categoria prescrita pelo título escolar.

Porém, como as classificações profissionais utilizadas pelas fontes têm forte caráter setorial, estando mais centradas no tipo de atividade que nas condições de seu exercício, e inclusive por se tratar de agrupamentos, uma forma de indicar seu significado quanto à posição social é relacioná-las aos recursos econômicos. $\mathrm{Na}$ inexistência de indicadores relativos ao montante do patrimônio, essas categorias ocupacionais podem ser relacionadas com o rendimento médio do trabalho principal, o que contribui também para especificar as diferenças de valor econômico de mercado da titulação escolar, contudo, uma melhor especificação requer um primeiro exame global do rendimento médio dos portadores de cada título escolar para então enfocar as diferenças entre os portadores de cada título conforme seu destino ocupacional.

\section{Titulação escolar, destinos ocupacionais e rendimento econômico}

O exame da hierarquização dos títulos escolares através do montante de rendimento do trabalho principal pode ser operacionalizado através da comparação dos títulos entre si, tomando o valor médio do conjunto dos portadores de cada título independentemente dos diferentes mercados em que se insere. Esse valor pode ser tomado inclusive como indicador indireto da hierarquização escolar, pelo menos no que tange à sua dimensão mais econômica ou mercadológica, mas a comparação também pode tomar cada título separadamente, em confronto com as diferentes ocupações em que seus portadores se inscrevem. Além dos respectivos mercados restritos a cada título, isso pode constituir um bom indicador das diferenças econômicas internas e, além disso, dos diferentes significados quanto à posição social, porque os portadores de um mesmo título podem ter ocupações e rendimentos mais próximos de posições socialmente dominantes na respectiva profissão (que também está inserida numa estrutura profissional e social socialmente hierarquizada) ou em ocupações social e/ou economicamente inferiores aos que exercem a ocupação correspondente ao título escolar.

Ao comparar o montante de rendimentos do trabalho principal para cada título universitário no período de 1970 a 2000, a primeira constatação geral que se depreende é de que, apesar das fortes variações em termos absolutos (devido, inclusive, às dificuldades técnicas de atualização monetária) ${ }^{8}$ as respectivas posições se alteram muito pouco. Além disso, muitas

\footnotetext{
${ }^{8} \mathrm{Na}$ exploração dos dados e nas tabelas, no Anexo, os valores
} monetários são o resultado da conversão da moeda brasileira do período para o dólar norte-americano. 
dessas pequenas variações podem ser atribuídas ao aparecimento de novos cursos e respectivos títulos e às reformulações e aos desdobramentos de cursos antigos. Outra constatação geral é que a altíssima diferença entre o título mais bem remunerado e aquele que ocupa a última posição se mantém relativamente constante. Deixando de lado os sem curso superior, a diferença entre o título do topo e o último título universitário é de 4,66 vezes em 2000, e o título que ocupa a posição extrema se aproxima da média de rendimento daqueles sem curso superior. Essa diferença era de 3,73 vezes em 1991, de 5,20 vezes em 1980 e, por fim, 4,94 vezes em 1970.

Outra constatação geral que se depreende é de que, embora o grau do título (graduação ou mestrado ou doutorado) tenha algum peso, a posição quase não depende da área de conhecimento, com exceção da situação geralmente inferior dos cursos de ciências humanas e dos cursos dirigidos à formação de professores de ensino de $1^{\circ}$ e $2^{\circ}$ grau. Portanto, mais do que à área, a posição ou o montante de rendimento está mais diretamente associado aos respectivos mercados ocupacionais. Assim, ao considerar os títulos mais bem posicionados, geralmente se trata de cursos nas áreas de ciências sociais aplicadas (graduação, mestrado ou doutorado em administração, direito, economia), nas engenharias em geral, os títulos mais valorizados na área de saúde ou ciências biológicas (graduação ou mestrado ou doutorado em medicina), nas ciências agrárias (agronomia, ciências agrárias) e cursos militares de nível superior, dentre outros, porém, ao tomar o extremo oposto, o das médias de rendimento do trabalho principal mais baixas, a principal característica comum é de que, em sua maior parte, se trata de cursos de licenciatura e bacharelado de todas as áreas de conhecimento, ou seja, é ter o magistério de ensino fundamental e médio como principal mercado, independentemente da área de conhecimento. Além desses, destacam-se também o curso de teologia, cujo mercado é muito específico, e aqueles de cunho prático com mercado restrito, como biblioteconomia e ciências da computação, dentre outros. Quanto a esse ponto também, considerando outros cortes no período em pauta para além de 2000, os resultados são muito semelhantes, não ocorrendo, portanto, maiores variações.

Mas, como já mencionado, se por um lado as diferenças entre os títulos escolares quanto ao rendimento médio do trabalho principal são extremamente acentuadas e as respectivas posições tendem a se manter no decorrer do período, por outro as variações entre os portadores do mesmo título ${ }^{9}$ são ainda mais acentuadas. Como seria excessivo tomar cada um das quase seis dezenas de títulos, podem ser enfocados alguns casos exemplares daqueles que ocupam posições extremas quanto às diferenças entre os títulos comparados entre si, para examinar mais detalhadamente suas diferenças internas quanto às variações no rendimento médio do trabalho principal e os mercados específicos que compõem os destinos ocupacionais.

Tomando inicialmente os portadores de títulos que ocupam posições extremas no polo do maior rendimento do trabalho principal, os com mestrado ou doutorado em administração distanciam-se um tanto relativamente das características médias do conjunto de portadores de titulação universitária. Uma característica específica consiste na maior associação com o universo empresarial e, particularmente, com os administradores e gerentes de empresas privadas (35,67\% daqueles com mestrado ou doutorado em administração), a exemplo daqueles de economia. Em contrapartida, há menor quantidade de professores de ensino superior $(8,62 \%)$, comparativamente aos demais portadores de título de mestrado ou doutorado. Mesmo assim, uma primeira constatação geral que se impõe relativamente àqueles com título de mestre ou doutor em administração é que, apesar de pouco mais da terça parte em que há correspondência entre o título e a ocupação de administrador e gerente de empresas privadas, ocorre enorme dispersão quanto ao destino ocupacional. Além dos mencionados administradores e gerentes de empresas privadas e de professores de ensino superior, destacam-se também os empregadores e

\footnotetext{
${ }^{9}$ Essa grande quantidade de títulos impossibilita inclusive a
} exposição das respectivas tabelas específicas no Anexo. 
proprietários em geral, que ocupam o topo das médias de rendimento. Além disso, mais da metade dos portadores do título de mestre ou doutor em administração enquadram-se em dezenas de outros agrupamentos que não aquele conforme as prescrições do título ou então que equivalem a posições de comando. Todas essas categorias de ocupações têm rendimento inferior.

Ao confrontar com aqueles que têm somente a graduação em administração, além da forte diferença na média do rendimento, ficam evidentes as diferenças quanto ao destino ocupacional. Nesse caso também os administradores e gerentes de empresas privadas representam boa parte - mais de um quinto -, bem como os empregadores e proprietários em geral - com quase a décima parte -, mas a proporção de professores de ensino superior é insignificante. Em contrapartida, a quantidade daqueles em ocupações subalternas, com rendimento médio abaixo daqueles da categoria dos administradores e gerentes de empresas privadas é muito maior, com bem mais da metade. No caso, as diferenças entre o rendimento médio dos empregadores e proprietários em geral é maior em confronto com os administradores e gerentes de empresas privadas. A maior parte dos graduados em administração tem ocupação com rendimento médio abaixo da respectiva categoria ocupacional dos administradores e gerentes de empresas privadas, com destaque para aqueles com funções burocráticas e de escritório, com quase um quinto do total, economistas, contadores e técnicos em administração e ocupações do comércio e atividades auxiliares, em quantidade ainda maior e com rendimento ainda menor, além de uma série extensa de outras ocupações.

Quando consideramos os portadores de outros títulos das chamadas ciências sociais aplicadas que se situam no polo do rendimento médio mais alto, os resultados não diferem muito desse padrão. No caso daqueles com mestrado ou doutorado em direito, que mantêm uma das posições das mais altas quanto ao rendimento médio, a maior parte tem ocupação em carreiras jurídicas, cujo rendimento médio está bem abaixo de uma série de outras ocupações que absorvem boa parte dos portadores desse título, particularmente os empregadores e proprietários em geral, diretores e chefes na administração pública, administradores e gerentes de empresas privadas, inclusive professores de ensino superior. Apesar disso, boa parte daqueles com mestrado ou doutorado em direito tem rendimento médio muito abaixo daqueles com carreiras jurídicas, numa série extensa de atividades, com destaque para as de segurança pública. Ao considerar aqueles apenas com graduação em direito, essas tendências se tornam ainda mais fortes. Nesse caso, a média de rendimentos é bem mais baixa e, quanto ao destino ocupacional, ocorre a diminuição das carreiras jurídicas, que continuam a representar mais da metade, com rendimento médio bem inferior às categorias de "elite", ou seja, empregadores e proprietários em geral, administradores e gerentes de empresas privadas e diretores e chefes na administração pública e professores de ensino superior, com quantidade insignificante. Em contrapartida, a quantidade daqueles em ocupações com rendimento inferior às profissões jurídicas aumenta, com destaque para as ocupações do comércio e atividades auxiliares, de segurança pública e as ocupações mal definidas.

No caso das ciências econômicas, essas tendências são muito semelhantes. Ao tomar os com mestrado ou doutorado em ciências econômicas e contábeis, apenas a quinta parte está incluída entre os economistas, contadores e técnicos em administração, com rendimento médio bem abaixo dos empregadores e proprietários em geral, diretores e chefes na administração pública e administradores e gerentes de empresas privadas, que absorve mais da quinta parte, e funções burocráticas e de escritório, mas bem acima dos professores de ensino superior, que nesse caso têm proporção mais alta. Mas nesse caso também uma boa parte tem ocupação com rendimento bem inferior àquele conforme a respectiva categoria do título escolar, como as ocupações do comércio e atividades auxiliares e as ocupações mal definidas. Ao considerar aqueles com somente graduação em economia, essas tendências se aprofundam. O rendimento médio reduz-se para pouco mais da metade daqueles com mestrado ou doutorado, os administradores e gerentes de empresas privadas 
absorvem mais da quinta parte e os ocupados como economistas diminuem, juntamente com o respectivo rendimento médio, e os professores de ensino superior quase desaparecem. Em contrapartida, os empregadores e proprietários em geral aumentam muito, tendo a melhor faixa de rendimento médio, seguidos pelos diretores e chefes na administração pública. No extremo oposto também aumentam muito as ocupações com rendimento médio bem abaixo dos economistas, contadores e técnicos em administração, tais como as ocupações do comércio e atividades auxiliares e as ocupações mal definidas.

Quando consideramos os titulados em cursos de áreas mais técnicas, essas tendências se mantêm com algumas variações. No caso daqueles com mestrado ou doutorado em engenharia, que possuem um dos rendimentos médios mais altos, pouco mais da quarta parte tem ocupação como engenheiro, com rendimento médio bem abaixo dos empregadores e proprietários em geral, dos diretores e chefes na administração pública e dos administradores e gerentes de empresas privadas, que têm participação muito alta, bem acima dos professores de ensino superior, que nesse caso também têm proporção importante, de quase um quinto dos portadores desse título, mas mesmo nesse caso, embora em menor grau, uma parte significativa (de quase metade) tem ocupação com rendimento médio muito inferior à respectiva categoria dos engenheiros e, inclusive, dos professores de ensino superior, como ocupações do comércio e atividades auxiliares, de defesa nacional e segurança pública e ocupações mal definidas. Ao tomar aqueles com apenas graduação em engenharia mecânica, o grau de polivalência nos usos do título escolar aumenta muito, embora o rendimento médio não esteja muito distante dos anteriores. Os ocupados como engenheiros equivalem a menos de uma terça parte, com rendimento médio muito abaixo das categorias de "elite", como os empregadores e proprietários em geral, que abrangem grande parte, mas também nesse caso quase a terça parte dos portadores do título de graduação em engenharia mecânica tem alguma ocupação com rendimento médio inferior aos ocupados como engenheiro, com maior concentração em ocupações da indústria em geral e ocupações do comércio e atividades auxiliares.

Com os graduados em engenharia civil, ocorre algo muito semelhante, apesar da maior quantidade dos que têm ocupação equivalente ao título, como engenheiro, que chega à metade, mas com rendimento médio bem abaixo de outras categorias. Dentre estas, destacam-se os empregadores e proprietários em geral e os administradores e gerentes de empresas privadas, ou seja, quase uma terça parte tem alguma ocupação com rendimento superior ao dos engenheiros. Em contrapartida, a quinta parte tem alguma ocupação com rendimento inferior ao dos engenheiros, particularmente em funções burocráticas e de escritório e em ocupações do comércio e atividades auxiliares. Os graduados em engenharia elétrica e eletrônica apresentam grau de dispersão e de diferenciação ainda maior, com pouco mais da terça parte com ocupação de engenheiro e com rendimento médio bem inferior ao dos empregadores e proprietários em geral, dentre outros. Os que têm ocupação cujo rendimento médio é inferior ao dos engenheiros passam da terça parte, com maior concentração nas ocupações da indústria em geral ou em ocupações como matemáticos, estatísticos e analistas de sistemas. Os graduados em engenharia química e industrial, bem como em outros cursos de engenharia, seguem esse mesmo padrão com apenas pequenas variações.

Outros cursos de cunho mais técnico, como o de geologia, não diferem muito dos de engenharia quanto a esse aspecto, porém, a exemplo daqueles mais associados a áreas como a biologia, os de engenharia mantêm um eixo de oposição interna no qual num polo se posicionam aqueles títulos com carreira mais determinada, como engenharia civil, e no polo oposto está uma série de cursos diversificados, geralmente de criação mais recente e com grau de profissionalização muito menor, e mais intensamente associados a categorias ocupacionais de "elite". É o caso daqueles classificados como outros cursos de graduação em engenharia. A quantidade de ocupados como engenheiros é muito pequena, com rendimento médio bem abaixo de uma série de outras ocupações 
exercidas por portadores desse tipo de título. Dentre estes, destacam-se os empregadores e proprietários em geral, que representam mais do dobro daqueles cuja ocupação é de engenheiro e os administradores e gerentes de empresas privadas, com uma quantidade ainda maior, ou seja, mais da quinta parte, além das ocupações mal definidas. Em contrapartida, mais da terça parte dos portadores desse tipo de título tem ocupação com rendimento médio menor que o dos engenheiros, particularmente nas ocupações do comércio e atividades auxiliares. Com o conjunto de cursos classificados como outros de ciências exatas e tecnológicas (exclusive graduação em engenharia), ocorre algo semelhante, apesar do rendimento médio bem abaixo dos demais e com grau de dispersão ocupacional e de rendimento médio ainda maior.

Essa posição de "franja" menos profissionalizada de alguns títulos ocorre também nas demais áreas, como nos cursos classificados como graduação em outros cursos de ciências biológicas e da saúde situados no polo oposto, ou seja, aquele correspondente ao menor rendimento médio. Nesse caso, mais da terça parte exerce alguma ocupação auxiliar de medicina e odontologia, com rendimento médio abaixo dos portadores desse tipo de título, e outro tanto como médicos, dentistas e assemelhados, com rendimento médio ainda menor. Isso não exclui a relativamente alta proporção de pertencentes a categorias de "elite", como a dos empregadores e proprietários em geral e administradores e gerentes de empresas privadas e, em contrapartida, a participação relativamente alta em ocupações com rendimento médio inferior aos médicos, dentistas e assemelhados.

Ao levar em conta os títulos escolares vinculados às ciências agrárias, ocorre algo muito semelhante, com o acréscimo da associação de parte dos portadores desses títulos com as atividades e a propriedade agropecuária. Daqueles com mestrado ou doutorado em ciências agrárias, menos da terça parte é formada por agrônomos, biólogos, veterinários e assemelhados, com rendimento abaixo da média do conjunto dos portadores desse título. Outra parcela significativa é formada por professores de ensino superior, com ren- dimento mais alto, mas inferior a uma série de categorias, como os administradores e gerentes de empresas privadas e os empregadores e proprietários em geral. Em contrapartida, a quinta parte tem alguma ocupação com rendimento médio inferior aos agrônomos. Ao tomar os que têm apenas a graduação em agronomia, além do rendimento médio menor, a proporção de agrônomos, biólogos, veterinários e assemelhados se mantém praticamente a mesma, mas aumenta muito a quantidade de empregadores e proprietários em geral e de administradores e gerentes de empresas privadas, com rendimento muito superior. Em contrapartida, mais da terça parte tem alguma ocupação com rendimento inferior ao dos agrônomos, com fortes variações, particularmente em funções burocráticas e de escritório. Mas, ao considerar os graduados em outros cursos de ciências agrárias - que não agronomia e medicina veterinária -, novamente fica evidente uma "franja" de menor grau de profissionalização e maior polivalência do título, além do menor rendimento, que os situa no polo do menor rendimento. Nesse caso, apenas uma pequena parte exerce ocupação na respectiva categoria, com rendimento muito inferior ao dos empregadores e proprietários em geral, cuja proporção se aproxima da dos administradores e gerentes de empresas privadas, mas também daqueles com ocupação na própria esfera de atividade, ou seja, na agropecuária e produção extrativa vegetal e animal e ocupações mal definidas e ocupações do comércio e atividades auxiliares e diretores e chefes na administração pública. Em contrapartida, mais da quarta parte dos portadores desse tipo de título tem ocupação com rendimento inferior ao da respectiva categoria de agrônomo ou assemelhado, particularmente, em funções burocráticas e de escritório e como professor de ensino médio. Para os graduados em medicina veterinária, os resultados são praticamente os mesmos.

Nesse polo constituído pelo rendimento médio mais alto, situam-se também alguns dos poucos títulos que mantêm alto grau de profissionalização e, portanto, de menor polivalência ocupacional. Embora se trate especialmente de títulos escolares ligados à medicina, mais que a área de conhecimento, a principal 
característica comum é o maior grau de autonomia, regulamentação e controle profissional. Como já foi mencionado, trata-se particularmente dos cursos de medicina (graduação, mestrado ou doutorado) e, por razões distintas, dos cursos militares de nível superior e, já numa situação intermediária quanto ao rendimento médio, de cursos como os de odontologia e geologia, dentre outros.

No caso daqueles com mestrado ou doutorado em medicina, três quartas partes têm ocupação como médico, e mais da décima parte como professor de ensino superior, que equivale a rendimentos médios um tanto mais baixos. Os empregadores e proprietários em geral e os administradores e gerentes de empresas privadas têm participação bem menor, embora com rendimento médio muito alto. Em contrapartida, a proporção daqueles que têm ocupação com rendimento médio menor que aquele dos médicos ou dos professores de ensino superior é bem menor, embora com muitas variações quanto às ocupações e ao rendimento médio. Ao tomar aqueles com apenas graduação em medicina, que também ocupam uma posição extrema no polo correspondente ao rendimento médio mais alto, a proporção daqueles ocupados como médicos é ainda maior, com quatro quintos, com rendimento médio próximo do topo; a de professor de ensino superior é insignificante. A proporção de empregadores e proprietários em geral aumenta, a exemplo dos administradores e gerentes de empresas privadas. Mesmo assim, boa parte tem ocupação com rendimento médio bem abaixo daquele da respectiva categoria dos médicos. No caso dos graduados em odontologia, apesar da semelhança com os médicos quanto ao grau de profissionalização, o rendimento médio é muito mais abaixo. Como já mencionado, a proporção daqueles com ocupação na própria profissão é a mais alta, e a dos empregadores e proprietários em geral e demais componentes da "elite" é baixa. Algo semelhante ocorre com aqueles com ocupação com rendimento médio abaixo daquele dos dentistas.

Quanto àqueles com cursos militares de nível superior, o alto grau de correspondência entre as prescrições do título escolar e a ocupação decorre evi- dentemente do controle burocrático tanto da formação como da carreira. Ainda assim, a proporção daqueles com ocupações de defesa nacional e segurança pública não passa muito da metade, com rendimento médio bem inferior a uma série de outras ocupações com participação significativa dos portadores desse tipo de título, o que pode estar fortemente associado às fases do ciclo de vida. Esse é o caso dos empregadores e proprietários em geral, diretores e chefes na administração pública e, particularmente, daqueles com ocupações dos transportes e comunicações, além dos administradores e gerentes de empresas privadas e ocupações mal definidas. Nesse caso, a proporção daqueles com ocupações com rendimento médio inferior à própria categoria é menor, mas não deixa de ser significativa, com quase a décima parte.

Passando para o polo oposto, aquele dos rendimentos médios mais baixos, há um conjunto de situações diferenciadas. Uma primeira divisão que se ressalta é aquela entre os cursos de licenciatura e os demais. Os de licenciatura, por definição, abrangem todas as áreas de conhecimento, pelo menos aquelas que fazem parte do ensino nos níveis pré-universitários, visto que constituem o principal mercado de destino ocupacional. Quanto aos demais, há uma série de cursos e respectivos títulos que, em sua maior parte, consistem em cursos técnicos de aplicação imediata, geralmente com mercado economicamente menos importante que os do polo de rendimento mais alto, mas com boa parte não necessariamente menos regulamentada em termos profissionais. Esse é particularmente o caso de cursos como serviço social, no extremo inferior do rendimento médio, seguido por outros com posição mais próxima da intermediária, como psicologia, farmácia, ciências contábeis e atuariais, comunicação social, ciências da computação, medicina veterinária e estatística, dentre outros. O curso que ocupa a posição extrema inferior quanto ao rendimento médio, com exceção daqueles de licenciatura, o de teologia, deve ser considerado um caso especial, visto que a maior parte dos portadores desse título tem como destino ocupacional um mercado instituído pelas Igrejas, com suas regras e condições próprias, 
mas, mesmo nesse caso, pouco mais da metade dos portadores do título exerce alguma ocupação como religioso, enquanto a quinta parte tem rendimento superior e mais da quarta parte tem alguma ocupação com rendimento inferior.

Isso, no entanto, não exclui as fortes diferenças internas entre os portadores de um mesmo título, cujas ocupações podem abranger diferentes mercados e condições de atuação. Para considerar apenas alguns casos exemplares, a maior parte dos graduados em serviço social classifica-se, em termos ocupacionais, como "cientista social", o que, apesar de estar de acordo com as prescrições burocráticas, não deixa de constituir uma situação muito ambivalente. Apesar disso, uma parte significativa exerce ocupações socialmente mais bem posicionadas e com rendimento superior ao dos "cientistas sociais", como os empregadores e proprietários em geral - apesar de bem abaixo daqueles da mesma categoria no polo do rendimento médio superior - e administradores e gerentes de empresas privadas. Em contrapartida, quase a terça parte dos portadores desse título tem alguma ocupação com rendimento médio inferior àquele da respectiva categoria dos "cientistas sociais", particularmente em funções burocráticas e de escritório e em ocupações do comércio e atividades auxiliares. Com os graduados em enfermagem há maior grau de profissionalização, tanto no sentido das prerrogativas e regulamentação do mercado como correspondência da ocupação com as prescrições do título. Bem mais da metade tem ocupação na respectiva categoria dos médicos, dentistas e assemelhados, mas isso não elimina a existência de quase a décima parte em ocupações com rendimento médio mais elevado e, em contrapartida, mais da quinta parte com rendimento médio inferior, particularmente em ocupações auxiliares da medicina e odontologia. Com os graduados em biblioteconomia ocorre algo muito semelhante.

Os graduados em psicologia têm maior grau de associação com categorias com posição social superior. Com menos da metade classificada na respectiva categoria de "cientista social" - que, apesar de oficial, também nesse caso comporta alto grau de ambivalência -, tem mais da quinta parte em ocupações com rendimento mais alto, particularmente como administradores e gerentes de empresas privadas e empregadores e proprietários em geral. Em contrapartida, quase a terça parte exerce ocupação com rendimento inferior à respectiva categoria de "cientista social", particularmente em funções burocráticas e de escritório e em ocupações do comércio e atividades auxiliares. Os graduados em farmácia não diferem muito desse padrão, a exemplo daqueles com graduação em medicina veterinária e em arquitetura e urbanismo.

Os graduados em comunicação social têm uma das menores proporções de correspondência entre a titulação e a respectiva categoria ocupacional: menos da quinta parte está incluída no agrupamento dos escritores e jornalistas, enquanto uma quantidade maior tem ocupação com rendimento mais alto, particularmente como administradores e gerentes de empresas privadas e empregadores e proprietários em geral. Em contrapartida, mais da metade dos portadores desse título exerce alguma ocupação com rendimento médio inferior ao da respectiva categoria dos escritores e jornalistas, particularmente em ocupações do comércio e atividades auxiliares, funções burocráticas e de escritório e como artistas e ocupações auxiliares. A situação dos graduados em propaganda e marketing aprofunda algumas dessas tendências, apesar das diferenças de rendimentos médios. Nesse caso, como profissão menos formalizada e associada ao universo empresarial, a categoria ocupacional com maior concentração é a dos administradores e gerentes de empresas privadas, com quase a terça parte, com forte participação também de outras ocupações com posição social mais alta, como os empregadores e proprietários em geral. Em contrapartida, a maior parte dos portadores desse título exerce ocupações com rendimento inferior à média, particularmente ocupações do comércio e atividades auxiliares, que representam mais da quinta parte, e funções burocráticas e de escritório. Apesar da distância quanto à área de conhecimento, a situação dos graduados em estatística é muito semelhante. $\mathrm{O}$ mesmo se aplica aos graduados em ciência da compu- 
tação e, num grau ainda mais elevado, aos graduados em ciências contábeis e atuariais, com menos da terça parte em ocupações da respectiva categoria de economistas, contadores e técnicos em administração, e mais de um quinto em ocupações com renda mais alta, particularmente como administradores e gerentes de empresas privadas e empregadores e proprietários em geral. Em contrapartida, quase metade tem rendimento inferior à respectiva categoria dos contadores, com maior concentração em funções burocráticas e de escritório, que absorvem a quinta parte.

Quanto aos títulos de cursos de licenciatura, sua posição no rendimento médio depende diretamente do grau de associação com o magistério de ensino de ensino médio e particularmente de ensino fundamental, e, além disso, da participação em outros mercados. Ao considerar os graduados em ciências, no extremo do polo do rendimento mais baixo daqueles com alguma titulação universitária, mais da terça parte tem como ocupação o magistério de ensino fundamental ou equivalente, particularmente de 5a a $8^{\underline{a}}$ série e do ensino médio, mas mesmo nesse caso uma parte exerce ocupações que representam posição social dominante, como empregadores e proprietários em geral e administradores e gerentes de empresas privadas, apesar de que com rendimentos bem inferiores aos homólogos com titulação escolar mais valorizada. Levando em conta os graduados em pedagogia, os resultados são muito semelhantes, apesar da maior participação daqueles com atividades auxiliares de ensino e dos administradores e gerentes de empresas privadas. No caso do curso de pedagogia, essa associação com ocupações do magistério de ensino fundamental e médio tem o efeito de posicionar inclusive aqueles com mestrado ou doutorado no polo dos rendimentos mais baixos, apesar da diferença ante os apenas graduados.

Algo muito semelhante ocorre com os de letras, os quais, tanto os apenas graduados como aqueles com mestrado ou doutorado, se situam no polo de rendimento mais baixo, apesar das diferenças. No caso dos graduados em letras, mais da metade tem ocupação de professor de ensino fundamental e mé- dio, que equivale às faixas mais baixas de rendimento dentre os portadores desse título. No que tange aos com mestrado ou doutorado em letras, as principais diferenças são a participação dos professores de ensino superior, com a quarta parte, que equivale à proporção de professores de ensino médio, com forte diferença quanto ao rendimento médio, e a menor participação dos professores de ensino fundamental.

Dentre os portadores de títulos de cursos de licenciatura, os graduados em física são os que mais se distanciam do extremo inferior de rendimentos, superando inclusive o rendimento médio de alguns portadores de títulos de mestrado ou doutorado, como os de pedagogia, porém isso está diretamente relacionado à menor proporção de professores de ensino fundamental e médio, maior proporção de professores de ensino médio, mas particularmente maior participação das categorias com rendimento médio alto. Além dos professores de ensino superior, trata-se especialmente dos administradores e gerentes de empresas privadas, matemáticos, estatísticos e analistas de sistemas, empregadores e proprietários em geral, inclusive em funções burocráticas e de escritório.

Quanto aos demais cursos de licenciatura, as tendências são muito semelhantes àquelas constatadas para os demais títulos cujos portadores têm o ensino fundamental e médio como principal mercado e destino ocupacional. Portanto, sua exposição detalhada não caberia.

\section{Considerações finais}

Como os dados apresentados evidenciam, a polivalência nos usos sociais e profissionais da titulação escolar, medida pelo grau de correspondência entre o título e a respectiva ocupação, é muito alta, embora com muitas variações. São poucos os títulos universitários em que seus portadores têm mais da metade exercendo alguma ocupação correspondente; além disso, esse grau de polivalência no geral tende a aumentar no período considerado. Para tanto, mais que a área de conhecimento dos cursos, são as possibilidades de usos sociais diferenciados dos títulos, seja 
em alguma ocupação acima ou abaixo da respectiva categoria ocupacional.

Conforme a principal hipótese explorada, essa forte polivalência decorre das relações dos portadores de titulação universitária com a "estrutura de poder". Mais especificamente, por um lado, a não correspondência entre o título escolar e a ocupação depende das relações com posições de "elite" e as respectivas ocupações de comando e gestão econômica e política, por outro, além dessas posições de "elite" e das ocupações mais centradas na respectiva profissão prescrita no título, boa parte dos portadores de titulação universitária exerce alguma ocupação com rendimento inferior àquele da ocupação correspondente ao título, ou seja, se, por um lado, boa parte exerce alguma ocupação com rendimento superior àquele auferido pelos que exercem a ocupação correspondente à profissão, por outro, outra parte, pelo menos em termos ocupacionais e econômicos, se encontra em posição inferior. Sendo assim, isso vai ao encontro da hipótese de que os portadores de título universitário têm diferentes mercados como destino ocupacional, sendo suas relações com a estrutura de poder e a respectiva posição social um condicionante geral.

Para a exploração dessas hipóteses, foram utilizadas algumas fontes censitárias cujos limites, especialmente seu alto grau de generalidade, não permitem melhor aprofundamento e especificação dos demais condicionantes dessa polivalência para além das relações entre titulação, ocupação e rendimento. Somente com a inclusão de fontes mais específicas é possível apreender as diferentes modalidades e estratégias práticas que podem estar na base das relações entre o mercado escolar e a ocupação profissional e os respectivos trajetos profissionais e sociais. Ao que tudo indica, essas modalidades podem abranger desde aqueles usos da titulação escolar de cunho mais estatutário da titulação escolar, como legitimação simbólica de posições de comando, como base de credenciais e acumulação de capital de relações e meio de reconversão profissional e social, dentre outras. Conforme mencionado, somente com a inclusão de fontes com informações mais específicas é possível maior aprofundamento desse tipo de questão, mas, em todo caso, como ponto de partida para tanto, aquilo que foi possível demonstrar com as fontes disponíveis pode ser indispensável.

\section{Referências bibliográficas}

ALVES, Ana Paula Salheb; ALMEIDA, Ana Maria Fonseca de. Qual é o valor do diploma? Um estudo sobre as práticas de recrutamento de grandes empresas da região de Campinas-SP. Cadernos de Pesquisa, maio 2009.

BARROS, Ricardo Paes de; MENDONÇA, Rosane. Salário e educação no Brasil. Rio de Janeiro: IPEA, 1996, mimeo.

BAUDELOT, Christian et al. Les effets de l'éducation: rapport à l'intention du piref. Paris: École Normale Supérieure, 2004.

BOIGEOL, A.; DEZALAY, Yves. De l'agent d'affaires au barreau: les conseils juridiques et la construction d'un espace professional. Genèses, v. 1, n. 27, p. 49-68, jun. 1997.

BOURDIEU, Pierre. Classement, déclassement, reclassement. Actes de la Recherche en Sciences Sociales, v. 24, p. 3-22, nov. 1978.

. Homo Academicus. Paris: Minuit, 1984.

. La Noblesse d'État: Grandes écoles et esprit de corps. Paris: Minuit, 1989.

BOURDIEU, Pierre; BOLTANSKI, L. Le titre et le poste: rapports entre le système de production et lê système de reproduction. $A c$ tes de la Recherche em Sciences Sociales, Paris, n. 2, p. 95-107, mar. 1975.

.; CHRISTIN, Rosine. La construction du marché: le champ administrative et la production de la politique du logement. Actes de la Recherche en Sciences Sociales, Paris, v. 81/82, p. 65-85, mar. 1990.

.; SAINT MARTIN. Monique de. Agrégration et segrégation. Le champ des grandes écoles et le champ du pouvoir. Actes de la Recherche en Sciences Sociales, Paris, v. 69, p. 2-50, set. 1987. BROWN, David K. The social sources of educational credencialism: status cultures, labor markets, and organizations. Sociology of Education, v. 74, n. 0, extra issue, p. 19-34, 2001.

COLLINS, Randall. The credential society. New York: Academic Press, 1979.

CORADINI, Odaci Luiz. As elites como objeto de estudo. In: (Org.). Estudos de grupos dirigentes no Rio Grande do Sul: algumas contribuições recentes. Porto Alegre: Editora da UFRGS, 2008. p. 7-18. 
DEZALAY, Yves. Les courtiers de l'international: héritiers cosmopolites, mercenaries de l'imperialisme et missionnaires de l'universel. Actes de la Recherche en Sciences Sociales, v. 151152, p. 5-35, mar. 2004.

.; GARTH, B. La mondialisation des guerres de palais. La restructuration du pouvoir d'État en Amérique Latine, entre notables du droit et "Chicago Boys". Paris: Seuil, 2002.

.; GARTH, B. L'imperialisme moral. Les juristes et l'imperialisme américain (Philippines, Indonésie). Actes de la Recherche em Sciences Sociales, v. 171-172, p. 40-55, mar. 2008. FERNANDEZ, Reynaldo; NARITA, Renata Del Tedesco. Instrução superior e mercado de trabalho no Brasil. Economia Aplicada, v. 5, n. 1, p. 7-32, 2001.

FLIGSTEIN, Neil. Markets as politics: a political-cultural approach to market instituitions. American Sociological Review, v. 61, p. 656-673, ago. 1996.

FREIDSON, Eliot. Renascimento do profissionalismo: teoria, profecia e política. São Paulo: EDUSP, 1998.

GARRIGOU, Alain. Les élites contre la République: Science Po et l'ENA. Paris: La Découverte, 2001.

GAUTIÉ, Jerôme; GODECHOT, Olivier; SORIGNET, PierreEmmanuel. Arrangement institucionnal et foncionnement du marche du travail. Le cas de la chasse de tête. Sociologie du Travail, 47, p. 383-404, 2005.

GRYNSZPAN, Mário. A teoria das elites e sua genealogia consagrada. $B I B$, n. 41 , p. 35-83, 1ํ semestre 1996.

IBGE. Censo Demográfico de 2000. Microdados. 3. ed. Rio de Janeiro: IBGE, 2003, CD-ROM.

Censo Demográfico de 1980. Microdados da Amostra. Rio de Janeiro: IBGE, 2006, CD-ROM.

Censo Demográfico de 1991. Microdados da Amostra. Rio de Janeiro: IBGE, 2006b, CD-ROM.

Censo Demográfico 1970. Microdados da Amostra de 25\%. Rio de Janeiro: IBGE, 2007, CD-ROM.

KARADY, Victor. Une "nation de juristes": des usages sociaux de la formation juridique dans la Hongrie d'ancien régime. Actes de la Recherche en Sciences Sociales, v. 86-87, p. 106-124, mar. 1991. MERLLIÉ, Dominique. Les catégories socio-professionnelles et les conditions de leur mise en oeuvre. Actes de la Recherche en Sciences Sociales, v. 50, p. 4-47, mar. 1983.

PARADEISE, Catherine. Les professions comme marches du travail fermés. Sociologie et Societés, v. XX, n. 2, p. 9-21, out. 1988.

SCHWARTZMAN, Simon. A revolução silenciosa do ensino superior. In: DURAN, Eunice R.; SAMPAIO, Helena. O Ensino Superior em Transformação. São Paulo, NUPES/USP, 2000. Disponível em: <http://www.schwartzman.org.br>. Acesso em: 20 dez. 2008.

VELOSO, Fernando et al. (Orgs.). Educação básica no Brasil: construindo o país do futuro. Rio de Janeiro: Elsevier, 2009.

WEBER, Max. Economía y sociedad: esbozo de sociología comprensiva. México: Fondo de Cultura Económica, 1984.

ZARCA, Bernard. Les patrons dans la statistique officielle française. Politix, v. 23, p. 44-65, troisième trimestre, 1993.

ZELIZER, Viviane. Repender le marché: la construction sociale du "marché aux bebés" aux Etas-Unis, 1870-1930. Actes de la Recherche en Sciences Sociales, v. 94, p. 3-26, set. 1992.

ODACI LUIZ CORADINI, doutor em antropologia social pelo Museu Nacional na Universidade Federal do Rio de Janeiro (UFRJ), com pós-doutorado na École des Hautes Études en Sciences Sociales (França), é professor associado da Universidade Federal do Rio Grande do Sul. Publicações recentes: Enseignement universitaire de théologie, les rapports centre/péripherie e les usages des sciences humaines et sociales (Cahiers de la Recherche sur l'Éducation et les Savoirs, v. 2, p. 93-116, jun. 2009; Associative/union commitement and the recruitment of political elites: recent trends in Brazil (International Journal of Contemporary Sociology, v. 44, n. 2, p. 201-227, out. 2007; Formation et insertion professionnelles des prefesseurs de sciences humaines et sociales au Rio Grande do Sul (Cahiers du Brésil Contemporain, n. 57-60, p. 223-259, 2005. Pesquisa em andamento, com apoio do INEP/CAPES/Observatório da Educação: "Ensino superior, carreiras profissionais e mercados de trabalho". E-mail: coradini@portoweb.com.br; coradini@ufrgs.br

Recebido em fevereiro de 2009 Aprovado em outubro de 2009 


\section{Anexo}

Tabela 1: Proporção dos portadores de titulação universitária exercendo ocupação correspondente em categorias com rendimento médio, superior e inferior em 2000

\begin{tabular}{|c|c|c|c|c|}
\hline Curso mais alto concluído & $\begin{array}{c}\text { Agrupamentos de categorias } \\
\text { ocupacionais }\end{array}$ & $\begin{array}{l}\text { \% portadores } \\
\text { do título escolar } \\
\text { que exercem } \\
\text { ocupação } \\
\text { correspondente }\end{array}$ & $\begin{array}{c}\text { \% categorias } \\
\text { ocupacionais } \\
\text { com rendimento } \\
\text { superior }\end{array}$ & $\begin{array}{c}\% \text { categorias } \\
\text { ocupacionais } \\
\text { com } \\
\text { rendimento } \\
\text { inferior }\end{array}$ \\
\hline Odontologia - graduação & $\begin{array}{c}\text { Médicos, dentistas e } \\
\text { assemelhados }\end{array}$ & 90,85 & 4,93 & 4,22 \\
\hline Medicina - graduação & $\begin{array}{c}\text { Médicos, dentistas e } \\
\text { assemelhados }\end{array}$ & 79,37 & 5,77 & 14,87 \\
\hline $\begin{array}{c}\text { Medicina - mestrado ou } \\
\text { doutorado }\end{array}$ & $\begin{array}{l}\text { Médicos, dentistas e } \\
\text { assemelhados }\end{array}$ & 74,99 & 4,95 & 20,06 \\
\hline Enfermagem - graduação & $\begin{array}{c}\text { Médicos, dentistas e } \\
\text { assemelhados }\end{array}$ & 68,31 & 9,85 & 21,84 \\
\hline $\begin{array}{l}\text { Direito - mestrado ou } \\
\text { doutorado }\end{array}$ & $\begin{array}{c}\text { Magistrados, advogados e } \\
\text { assemelhados }\end{array}$ & 65,45 & 9,93 & 24,62 \\
\hline Militar & $\begin{array}{c}\text { Ocupações da defesa } \\
\text { nacional e segurança pública }\end{array}$ & 62,12 & 28,5 & 9,38 \\
\hline $\begin{array}{c}\text { Arquitetura e Urbanismo - } \\
\text { graduação }\end{array}$ & $\begin{array}{c}\text { Engenheiros, arquitetos e } \\
\text { assemelhados }\end{array}$ & 60,01 & 19,06 & 20,93 \\
\hline Direito - graduação & $\begin{array}{c}\text { Magistrados, advogados e } \\
\text { assemelhados }\end{array}$ & 58,42 & 12,79 & 28,79 \\
\hline $\begin{array}{l}\text { Medicina Veterinária - } \\
\text { graduação }\end{array}$ & $\begin{array}{c}\text { Agrônomos, biólogos, } \\
\text { veterinários e assemelhados }\end{array}$ & 57,55 & 26,56 & 15,9 \\
\hline Biblioteconomia - graduação & $\begin{array}{l}\text { Outras ocupações técnicas, } \\
\text { científicas e assemelhadas }\end{array}$ & 52,94 & 15,49 & 31,56 \\
\hline Serviço Social - graduação & Cientistas sociais & 52,92 & 16,82 & 30,26 \\
\hline Farmácia - graduação & $\begin{array}{l}\text { Químicos, farmacêuticos, } \\
\text { físicos e assemelhados }\end{array}$ & 51,91 & 39,9 & 8,19 \\
\hline Teologia - graduação & Religiosos & 51,39 & 21,72 & 26,89 \\
\hline Engenharia Civil - graduação & $\begin{array}{c}\text { Engenheiros, arquitetos e } \\
\text { assemelhados }\end{array}$ & 50,8 & 28,36 & 20,84 \\
\hline Educação Física - graduação & $\begin{array}{l}\text { Ocupações de prestação de } \\
\text { serviços e por conta própria }\end{array}$ & 49,96 & 41,78 & 8,26 \\
\hline Psicologia - graduação & Cientistas sociais & 46,79 & 23,84 & 29,37 \\
\hline Geologia - graduação & $\begin{array}{l}\text { Químicos, farmacêuticos, } \\
\text { físicos e assemelhados }\end{array}$ & 44,56 & 19,49 & 35,95 \\
\hline $\begin{array}{l}\text { Ciências da Computação - } \\
\text { graduação }\end{array}$ & $\begin{array}{c}\text { Matemáticos, estatísticos e } \\
\text { analistas de sistemas }\end{array}$ & 37,98 & 14,73 & 47,29 \\
\hline Física - graduação & Professores de ensino médio & 37,79 & 55,07 & 7,14 \\
\hline $\begin{array}{c}\text { Outros de Ciências Biológicas e } \\
\text { da Saúde - graduação }\end{array}$ & $\begin{array}{l}\text { Ocupações auxiliares da } \\
\text { medicina e odontologia }\end{array}$ & 37,03 & 16,49 & 46,49 \\
\hline $\begin{array}{c}\text { Engenharia Elétrica e Eletrônica } \\
\text { - graduação }\end{array}$ & $\begin{array}{c}\text { Engenheiros, arquitetos e } \\
\text { assemelhados }\end{array}$ & 36,64 & 28,05 & 35,31 \\
\hline $\begin{array}{l}\text { Administração - mestrado ou } \\
\text { doutorado }\end{array}$ & $\begin{array}{c}\text { Administradores e gerentes } \\
\text { de empresas privadas }\end{array}$ & 35,69 & 7,35 & 56,96 \\
\hline Geografia - graduação & Professores de ensino médio & 34,15 & 31,9 & 33,95 \\
\hline História - graduação & Professores de ensino médio & 33,23 & 40,27 & 26,51 \\
\hline
\end{tabular}


(continuação)

\begin{tabular}{|c|c|c|c|c|}
\hline Curso mais alto concluído & $\begin{array}{c}\text { Agrupamentos de categorias } \\
\text { ocupacionais }\end{array}$ & $\begin{array}{c}\text { \% portadores } \\
\text { do título escolar } \\
\text { que exercem } \\
\text { ocupação } \\
\text { correspondente }\end{array}$ & $\begin{array}{c}\text { \% categorias } \\
\text { ocupacionais } \\
\text { com rendimento } \\
\text { superior }\end{array}$ & $\begin{array}{c}\% \text { categorias } \\
\text { ocupacionais } \\
\text { com } \\
\text { rendimento } \\
\text { inferior }\end{array}$ \\
\hline Agronomia - graduação & $\begin{array}{c}\text { Agrônomos, biólogos, } \\
\text { veterinários e assemelhados }\end{array}$ & 31,63 & 30,13 & 38,24 \\
\hline $\begin{array}{c}\text { Outros de Ciências Biológicas } \\
\text { e da Saúde - mestrado ou } \\
\text { doutorado }\end{array}$ & $\begin{array}{l}\text { Médicos, dentistas e } \\
\text { assemelhados }\end{array}$ & 31,39 & 32,19 & 20,06 \\
\hline $\begin{array}{c}\text { Ciências Contábeis e Atuariais - } \\
\text { graduação }\end{array}$ & $\begin{array}{l}\text { Economistas, contadores e } \\
\text { técnicos em administração }\end{array}$ & 31,32 & 23,6 & 45,08 \\
\hline Matemática - graduação & Professores de ensino médio & 31,06 & 47,13 & 21,81 \\
\hline $\begin{array}{c}\text { Engenharia Mecânica - } \\
\text { graduação }\end{array}$ & $\begin{array}{c}\text { Engenheiros, arquitetos e } \\
\text { assemelhados }\end{array}$ & 30,78 & 37,63 & 31,59 \\
\hline $\begin{array}{c}\text { Ciências Agrárias - mestrado ou } \\
\text { doutorado }\end{array}$ & $\begin{array}{c}\text { Agrônomos, biólogos, } \\
\text { veterinários e assemelhados }\end{array}$ & 30,15 & 49,8 & 20,05 \\
\hline Letras - graduação & Professores de ensino médio & 28,85 & 42,39 & 28,76 \\
\hline $\begin{array}{c}\text { Engenharia - mestrado ou } \\
\text { doutorado }\end{array}$ & $\begin{array}{c}\text { Engenheiros, arquitetos e } \\
\text { assemelhados }\end{array}$ & 27,2 & 25,46 & 47,34 \\
\hline Biologia - graduação & Professores de ensino médio & 27,03 & 54,32 & 18,66 \\
\hline $\begin{array}{c}\text { Letras e Artes - mestrado ou } \\
\text { doutorado }\end{array}$ & Professores de ensino médio & 25,54 & 59,53 & 14,93 \\
\hline Química - graduação & Professores de ensino médio & 24,38 & 68,84 & 6,67 \\
\hline $\begin{array}{l}\text { Engenharia Química e Industrial } \\
\text { - graduação }\end{array}$ & $\begin{array}{c}\text { Químicos, farmacêuticos, } \\
\text { físicos e assemelhados }\end{array}$ & 24,05 & 35,81 & 40,15 \\
\hline Administração - graduação & $\begin{array}{c}\text { Administradores e gerentes } \\
\text { de empresas privadas }\end{array}$ & 23,82 & 12 & 64,18 \\
\hline $\begin{array}{c}\text { Propaganda e Marketing - } \\
\text { graduação }\end{array}$ & $\begin{array}{c}\text { Ocupações do comércio e } \\
\text { atividades auxiliares }\end{array}$ & 22,7 & 53,76 & 23,54 \\
\hline $\begin{array}{c}\text { Ciências Econômicas e } \\
\text { Contábeis - mestrado ou } \\
\text { doutorado }\end{array}$ & $\begin{array}{l}\text { Economistas, contadores e } \\
\text { técnicos em administração }\end{array}$ & 19,98 & 36,7 & 43,31 \\
\hline $\begin{array}{c}\text { Comunicação Social - } \\
\text { graduação }\end{array}$ & Escritores e jornalistas & 18,35 & 20,48 & 61,17 \\
\hline Estatística - graduação & $\begin{array}{c}\text { Matemáticos, estatísticos e } \\
\text { analistas de sistemas }\end{array}$ & 18,33 & 29,6 & 52,07 \\
\hline Filosofia - graduação & Professores de ensino médio & 16,17 & 62,26 & 21,57 \\
\hline $\begin{array}{l}\text { Outros de Ciências Exatas } \\
\text { e Tecnológicas (exclusive } \\
\text { graduação em engenharia) }\end{array}$ & $\begin{array}{c}\text { Engenheiros, arquitetos e } \\
\text { assemelhados }\end{array}$ & 15,89 & 40,92 & 43,19 \\
\hline Ciências - graduação & Professores de ensino médio & 15,55 & 48,09 & 36,35 \\
\hline $\begin{array}{l}\text { Pedagogia - mestrado ou } \\
\text { doutorado } \\
\end{array}$ & $\begin{array}{c}\text { Ocupações auxiliares do } \\
\text { ensino } \\
\end{array}$ & 15,52 & 43,68 & 40,79 \\
\hline $\begin{array}{c}\text { Ciências Econômicas - } \\
\text { graduação }\end{array}$ & $\begin{array}{l}\text { Economistas, contadores e } \\
\text { técnicos em administração }\end{array}$ & 14,68 & 40 & 45,32 \\
\hline $\begin{array}{l}\text { Outros de Ciências Humanas e } \\
\text { Sociais - mestrado ou doutorado }\end{array}$ & Cientistas sociais & 14,23 & 52,78 & 33 \\
\hline Pedagogia - graduação & $\begin{array}{c}\text { Ocupações auxiliares do } \\
\text { ensino }\end{array}$ & 14,19 & 21,04 & 64,77 \\
\hline $\begin{array}{c}\text { Outros de Ciências Agrárias - } \\
\text { graduação }\end{array}$ & $\begin{array}{c}\text { Agrônomos, biólogos, } \\
\text { veterinários e assemelhados }\end{array}$ & 13,91 & 59,28 & 26,8 \\
\hline
\end{tabular}




\begin{tabular}{|c|c|c|c|c|}
\hline Curso mais alto concluído & $\begin{array}{c}\text { Agrupamentos de categorias } \\
\text { ocupacionais }\end{array}$ & $\begin{array}{l}\text { \% portadores } \\
\text { do título escolar } \\
\text { que exercem } \\
\text { ocupação } \\
\text { correspondente }\end{array}$ & $\begin{array}{c}\text { \% categorias } \\
\text { ocupacionais } \\
\text { com rendimento } \\
\text { superior }\end{array}$ & $\begin{array}{l}\text { \% categorias } \\
\text { ocupacionais } \\
\text { com } \\
\text { rendimento } \\
\text { inferior }\end{array}$ \\
\hline Artes - graduação & $\begin{array}{c}\text { Artistas e ocupações afins e } \\
\text { auxiliares }\end{array}$ & 13,34 & 13,75 & 72,91 \\
\hline $\begin{array}{c}\text { Outros de Ciências Exatas e } \\
\text { Tecnológicas (exclusive mestrado } \\
\text { ou doutorado em Engenharia) }\end{array}$ & Professores de ensino médio & 11,83 & 84,88 & 3,29 \\
\hline $\begin{array}{c}\text { Ciências e Estudos Sociais - } \\
\text { graduação }\end{array}$ & Professores de ensino médio & 11,63 & 62,86 & 25,51 \\
\hline Outros cursos de graduação & Professores de ensino médio & 9,28 & 74,03 & 16,69 \\
\hline $\begin{array}{c}\text { Formação de professores - } \\
\text { disciplinas especiais - graduação }\end{array}$ & Professores de ensino médio & 8,92 & 78,48 & 12,6 \\
\hline $\begin{array}{c}\text { Outros cursos de mestrado ou } \\
\text { doutorado }\end{array}$ & Professores de ensino médio & 6,73 & 85,02 & 8,26 \\
\hline $\begin{array}{l}\text { Outros cursos de Engenharia - } \\
\text { graduação }\end{array}$ & $\begin{array}{c}\text { Engenheiros, arquitetos e } \\
\text { assemelhados }\end{array}$ & 5,21 & 54,78 & 40,01 \\
\hline $\begin{array}{l}\text { Outros de Letras e Artes - } \\
\text { graduação }\end{array}$ & Professores de ensino médio & 4,97 & 76,39 & 18,64 \\
\hline $\begin{array}{l}\text { Outros de Ciências Humanas e } \\
\text { Sociais - graduação }\end{array}$ & Professores de ensino médio & 3,9 & 80,13 & 15,97 \\
\hline
\end{tabular}

Tabela 2: Titulação escolar e rendimento médio do trabalho principal - Curso mais alto concluído/ rendimento médio (U\$) em ordem decrescente

\begin{tabular}{|c|c|c|c|c|c|c|c|}
\hline & 2000 & & 1991 & & 1980 & & 1970 \\
\hline $\begin{array}{l}\text { Administração } \\
\text { - mestrado ou } \\
\text { doutorado }\end{array}$ & 2673,68 & $\begin{array}{l}\text { Direito - mestrado } \\
\text { ou doutorado }\end{array}$ & 2390,02 & $\begin{array}{l}\text { Administração - } \\
\text { mestrado }\end{array}$ & 1827,37 & Engenharia & 629,78 \\
\hline $\begin{array}{l}\text { Medicina - } \\
\text { mestrado ou } \\
\text { doutorado }\end{array}$ & 2483,28 & $\begin{array}{l}\text { Outros cursos } \\
\text { de Engenharia - } \\
\text { graduação }\end{array}$ & 2320,02 & $\begin{array}{l}\text { Engenharia - } \\
\text { mestrado }\end{array}$ & 1793,94 & Medicina & 584,06 \\
\hline $\begin{array}{l}\text { Direito - mestrado } \\
\text { ou doutorado }\end{array}$ & 2438,45 & $\begin{array}{l}\text { Administração - } \\
\text { mestrado ou } \\
\text { doutorado }\end{array}$ & 2270,5 & $\begin{array}{l}\text { Economia - } \\
\text { mestrado }\end{array}$ & 1668,37 & Administração & 519,37 \\
\hline $\begin{array}{l}\text { Ciências } \\
\text { Econômicas } \\
\text { e Contábeis - } \\
\text { mestrado ou } \\
\text { doutorado }\end{array}$ & 2346,93 & $\begin{array}{l}\text { Engenharia - } \\
\text { mestrado ou } \\
\text { doutorado }\end{array}$ & 2217,87 & $\begin{array}{l}\text { Engenharia - } \\
\text { superior }\end{array}$ & 1531,04 & Arquitetura & 512,93 \\
\hline $\begin{array}{l}\text { Engenharia - } \\
\text { mestrado ou } \\
\text { doutorado }\end{array}$ & 2328,77 & $\begin{array}{l}\text { Medicina - } \\
\text { mestrado ou } \\
\text { doutorado }\end{array}$ & 2163,66 & $\begin{array}{l}\text { Topografia - } \\
\text { superior }\end{array}$ & 1478,55 & Militar superior & 509,79 \\
\hline $\begin{array}{l}\text { Outros cursos } \\
\text { de Engenharia - } \\
\text { graduação }\end{array}$ & 2090,12 & $\begin{array}{l}\text { Outros de } \\
\text { Ciências Humanas } \\
\text { e Sociais - } \\
\text { graduação }\end{array}$ & 2120,16 & $\begin{array}{l}\text { Química - } \\
\text { superior }\end{array}$ & 1439,60 & Economia & 488,93 \\
\hline $\begin{array}{l}\text { Medicina - } \\
\text { graduação }\end{array}$ & 1928,92 & $\begin{array}{l}\text { Ciências } \\
\text { Econômicas } \\
\text { e Contábeis - } \\
\text { mestrado ou } \\
\text { doutorado }\end{array}$ & 2089,82 & $\begin{array}{l}\text { Eletricidade - } \\
\text { superior }\end{array}$ & 1431,70 & Direito & 478,28 \\
\hline
\end{tabular}


(continuação)

\begin{tabular}{|c|c|c|c|c|c|c|c|}
\hline & 2000 & & 1991 & & 1980 & & 1970 \\
\hline $\begin{array}{l}\text { Engenharia } \\
\text { Mecânica - } \\
\text { graduação }\end{array}$ & 1866,56 & $\begin{array}{l}\text { Engenharia } \\
\text { Mecânica - } \\
\text { graduação }\end{array}$ & 2053,00 & $\begin{array}{l}\text { Engenharia - } \\
\text { superior }\end{array}$ & 1356,46 & $\begin{array}{l}\text { Química } \\
\text { Industrial }\end{array}$ & 470,66 \\
\hline $\begin{array}{l}\text { Engenharia Civil - } \\
\text { graduação }\end{array}$ & 1828,58 & $\begin{array}{l}\text { Outros cursos } \\
\text { de mestrado ou } \\
\text { doutorado }\end{array}$ & 1989,12 & $\begin{array}{l}\text { Geologia - } \\
\text { superior }\end{array}$ & 1329,14 & $\begin{array}{l}\text { Contabilidade ou } \\
\text { atuária }\end{array}$ & 400,20 \\
\hline $\begin{array}{l}\text { Outros cursos } \\
\text { de mestrado ou } \\
\text { doutorado }\end{array}$ & 1799,30 & $\begin{array}{l}\text { Medicina - } \\
\text { graduação }\end{array}$ & 1985,61 & Academia militar & 1309,67 & Agronomia & 390,21 \\
\hline $\begin{array}{l}\text { Engenharia Elétrica } \\
\text { e Eletrônica - } \\
\text { graduação }\end{array}$ & 1791,39 & $\begin{array}{l}\text { Engenharia Civil - } \\
\text { Graduação }\end{array}$ & 1939,18 & $\begin{array}{l}\text { Medicina - } \\
\text { mestrado }\end{array}$ & 1303,18 & $\begin{array}{l}\text { Matemática, } \\
\text { Física e Química }\end{array}$ & 385,30 \\
\hline $\begin{array}{l}\text { Outros de } \\
\text { Ciências Exatas } \\
\text { e Tecnológicas, } \\
\text { exceto Engenharia } \\
\text { - mestrado ou } \\
\text { doutorado } \\
\end{array}$ & 1779,41 & $\begin{array}{l}\text { Direito - } \\
\text { graduação }\end{array}$ & 1813,92 & $\begin{array}{l}\text { Direito - } \\
\text { mestrado }\end{array}$ & 1296,23 & $\begin{array}{l}\text { Estatística } \\
\text { superior }\end{array}$ & 365,52 \\
\hline Militar & 1761,41 & $\begin{array}{l}\text { Outros de } \\
\text { Ciências Exatas } \\
\text { e Tecnológicas, } \\
\text { exceto } \\
\text { Engenharia - } \\
\text { mestrado ou } \\
\text { doutorado }\end{array}$ & 1783,27 & $\begin{array}{l}\text { Computação - } \\
\text { mestrado }\end{array}$ & 1271,17 & Odontologia & 356,56 \\
\hline $\begin{array}{l}\text { Ciências Agrárias } \\
\text { - mestrado ou } \\
\text { doutorado }\end{array}$ & 1717,93 & $\begin{array}{l}\text { Outros de } \\
\text { Ciências Exatas } \\
\text { e Tecnológicas, } \\
\text { exceto } \\
\text { Engenharia - } \\
\text { graduação }\end{array}$ & 1775,48 & $\begin{array}{l}\text { Agronomia - } \\
\text { mestrado }\end{array}$ & 1231,59 & Veterinária & 355,25 \\
\hline $\begin{array}{l}\text { Engenharia } \\
\text { Química e } \\
\text { Industrial - } \\
\text { graduação }\end{array}$ & 1692,78 & $\begin{array}{l}\text { Letras e Artes - } \\
\text { mestrado ou } \\
\text { doutorado }\end{array}$ & 1771,60 & $\begin{array}{l}\text { Economia - } \\
\text { superior }\end{array}$ & 1192,93 & Outros superiores & 325,28 \\
\hline $\begin{array}{l}\text { Geologia - } \\
\text { graduação }\end{array}$ & 1643,22 & $\begin{array}{l}\text { Geologia - } \\
\text { graduação }\end{array}$ & 1767,83 & $\begin{array}{l}\text { Medicina - } \\
\text { superior }\end{array}$ & 1095,95 & Psicologia & 311,19 \\
\hline $\begin{array}{l}\text { Outros de Ciências } \\
\text { Biológicas e da } \\
\text { Saúde - mestrado } \\
\text { ou doutorado }\end{array}$ & 1572,26 & $\begin{array}{l}\text { Arquitetura e } \\
\text { Urbanismo - } \\
\text { graduação }\end{array}$ & 1763,54 & $\begin{array}{l}\text { Agrícola - } \\
\text { superior }\end{array}$ & 1065,38 & $\begin{array}{l}\text { Farmácia ou } \\
\text { Bioquímica }\end{array}$ & 287,39 \\
\hline $\begin{array}{l}\text { Direito - } \\
\text { graduação }\end{array}$ & 1569,32 & $\begin{array}{l}\text { Ciências } \\
\text { Econômicas - } \\
\text { graduação }\end{array}$ & 1758,44 & Direito - superior & 1042,04 & $\begin{array}{l}\text { Educação Física } \\
\text { superior }\end{array}$ & 266,98 \\
\hline $\begin{array}{l}\text { Ciências } \\
\text { Econômicas - } \\
\text { graduação }\end{array}$ & 1542,80 & $\begin{array}{l}\text { Engenharia Elétrica } \\
\text { e Eletrônica - } \\
\text { graduação }\end{array}$ & 1752,15 & $\begin{array}{l}\text { Arquitetura - } \\
\text { superior }\end{array}$ & 977,08 & Letras & 251,43 \\
\hline $\begin{array}{l}\text { Outros de Ciências } \\
\text { Humanas e Sociais } \\
\text { - mestrado ou } \\
\text { doutorado }\end{array}$ & 1510,47 & $\begin{array}{l}\text { Engenharia } \\
\text { Química e } \\
\text { Industrial - } \\
\text { graduação }\end{array}$ & 1741,82 & $\begin{array}{l}\text { Estatística - } \\
\text { superior }\end{array}$ & 976,05 & $\begin{array}{l}\text { Geografia ou } \\
\text { História }\end{array}$ & 250,58 \\
\hline $\begin{array}{l}\text { Propaganda e } \\
\text { Marketing - } \\
\text { graduação }\end{array}$ & 1439,66 & $\begin{array}{l}\text { Ciências Agrárias } \\
\text { - mestrado ou } \\
\text { doutorado }\end{array}$ & 1714,09 & $\begin{array}{l}\text { Administração - } \\
\text { superior }\end{array}$ & 963,58 & Ciências Sociais & 246,33 \\
\hline
\end{tabular}


(continuação)

\begin{tabular}{|c|c|c|c|c|c|c|c|}
\hline & 2000 & & 1991 & & 1980 & & 1970 \\
\hline $\begin{array}{l}\text { Agronomia - } \\
\text { graduação }\end{array}$ & 1375,49 & $\begin{array}{l}\text { Outros de } \\
\text { Ciências Humanas } \\
\text { e Sociais - } \\
\text { mestrado ou } \\
\text { doutorado }\end{array}$ & 1680,71 & $\begin{array}{l}\text { Química - } \\
\text { bacharelado }\end{array}$ & 952,57 & História Natural & 239,49 \\
\hline $\begin{array}{l}\text { Administração - } \\
\text { graduação }\end{array}$ & 1300,40 & Militar & 1680,49 & $\begin{array}{l}\text { Biologia - } \\
\text { mestrado }\end{array}$ & 896,42 & $\begin{array}{l}\text { Belas-Artes } \\
\text { superior }\end{array}$ & 233,53 \\
\hline $\begin{array}{l}\text { Odontologia - } \\
\text { graduação }\end{array}$ & 1298,91 & $\begin{array}{l}\text { Administração - } \\
\text { graduação }\end{array}$ & 1562,06 & $\begin{array}{l}\text { Computação - } \\
\text { bacharelado }\end{array}$ & 890,09 & Filosofia & 233,50 \\
\hline $\begin{array}{l}\text { Arquitetura e } \\
\text { Urbanismo - } \\
\text { graduação }\end{array}$ & 1286,77 & $\begin{array}{l}\text { Outros de } \\
\text { Ciências Biológicas } \\
\text { e da Saúde - } \\
\text { mestrado ou } \\
\text { doutorado } \\
\end{array}$ & 1555,17 & $\begin{array}{l}\text { Biblioteconomia - } \\
\text { mestrado }\end{array}$ & 876,39 & $\begin{array}{l}\text { Serviço Social } \\
\text { superior }\end{array}$ & 209,54 \\
\hline $\begin{array}{l}\text { Estatística - } \\
\text { graduação }\end{array}$ & 1279,41 & $\begin{array}{l}\text { Pedagogia - } \\
\text { mestrado ou } \\
\text { doutorado }\end{array}$ & 1510,38 & Dentistas & 874,98 & $\begin{array}{l}\text { Enfermagem } \\
\text { superior }\end{array}$ & 201,10 \\
\hline $\begin{array}{l}\text { Outros de } \\
\text { Ciências Exatas } \\
\text { e Tecnológicas, } \\
\text { exceto Engenharia } \\
\text { - graduação }\end{array}$ & 1277,27 & $\begin{array}{l}\text { Outros cursos de } \\
\text { graduação }\end{array}$ & 1453,83 & $\begin{array}{l}\text { Contabilidade - } \\
\text { superior }\end{array}$ & 861,69 & Pedagogia & 199,98 \\
\hline $\begin{array}{l}\text { Letras e Artes } \\
\text { - mestrado ou } \\
\text { doutorado }\end{array}$ & 1235,58 & $\begin{array}{l}\text { Odontologia - } \\
\text { graduação }\end{array}$ & 1451,37 & $\begin{array}{l}\text { Física - } \\
\text { bacharelado }\end{array}$ & 839,91 & $\begin{array}{l}\text { Grau } \\
\text { indeterminado }\end{array}$ & 182,40 \\
\hline $\begin{array}{l}\text { Medicina } \\
\text { Veterinária - } \\
\text { graduação }\end{array}$ & 1231,65 & $\begin{array}{l}\text { Comunicação } \\
\text { Social - graduação }\end{array}$ & 1440,91 & $\begin{array}{l}\text { Astronomia - } \\
\text { superior }\end{array}$ & 812,86 & $\begin{array}{l}\text { Eclesiástico } \\
\text { superior }\end{array}$ & 123,96 \\
\hline Física - graduação & 1159,87 & $\begin{array}{l}\text { Química - } \\
\text { graduação }\end{array}$ & 1396,16 & $\begin{array}{l}\text { Veterinária - } \\
\text { superior }\end{array}$ & 806,62 & $\begin{array}{l}\text { NR/NA (sem } \\
\text { curso, sem } \\
\text { informação) }\end{array}$ & 53,80 \\
\hline $\begin{array}{l}\text { Ciências da } \\
\text { Computação - } \\
\text { graduação }\end{array}$ & 1156,11 & $\begin{array}{l}\text { Estatística - } \\
\text { graduação }\end{array}$ & 1373,04 & $\begin{array}{l}\text { Agrimensura - } \\
\text { superior }\end{array}$ & 754,04 & & \\
\hline $\begin{array}{l}\text { Comunicação } \\
\text { Social - graduação }\end{array}$ & 1121,55 & $\begin{array}{l}\text { Agronomia - } \\
\text { graduação }\end{array}$ & 1372,71 & Artes - mestrado & 733,28 & & \\
\hline $\begin{array}{l}\text { Outros de } \\
\text { Ciências Agrárias - } \\
\text { graduação }\end{array}$ & 1108,7 & $\begin{array}{l}\text { Teologia - } \\
\text { graduação }\end{array}$ & 1341,48 & $\begin{array}{l}\text { Educação - } \\
\text { mestrado }\end{array}$ & 701,40 & & \\
\hline $\begin{array}{l}\text { Química - } \\
\text { graduação }\end{array}$ & 1100,84 & Física - graduação & 1335,45 & $\begin{array}{l}\text { Farmácia - } \\
\text { superior }\end{array}$ & 662,04 & & \\
\hline $\begin{array}{l}\text { Outros de Ciências } \\
\text { Humanas e Sociais } \\
\text { - graduação }\end{array}$ & 1078,20 & $\begin{array}{l}\text { Medicina } \\
\text { Veterinária - } \\
\text { graduação }\end{array}$ & 1317,67 & $\begin{array}{l}\text { Diplomacia - } \\
\text { superior }\end{array}$ & 650,52 & & \\
\hline $\begin{array}{l}\text { Ciências Contábeis } \\
\text { e Atuariais - } \\
\text { graduação }\end{array}$ & 1059,80 & $\begin{array}{l}\text { Ciências da } \\
\text { Computação - } \\
\text { graduação }\end{array}$ & 1310,44 & $\begin{array}{l}\text { Comunicações - } \\
\text { superior }\end{array}$ & 649,32 & & \\
\hline $\begin{array}{l}\text { Formação de } \\
\text { professores - } \\
\text { disciplinas especiais } \\
\text { - graduação }\end{array}$ & 1038,16 & $\begin{array}{l}\text { Psicologia - } \\
\text { graduação }\end{array}$ & 1301,54 & $\begin{array}{l}\text { Museologia - } \\
\text { superior }\end{array}$ & 564,52 & & \\
\hline $\begin{array}{l}\text { Pedagogia - } \\
\text { mestrado ou } \\
\text { doutorado }\end{array}$ & 1033,69 & $\begin{array}{l}\text { Ciências Contábeis } \\
\text { e Atuariais - } \\
\text { graduação }\end{array}$ & 1245,40 & $\begin{array}{l}\text { Matemática - } \\
\text { bacharelado }\end{array}$ & 554,27 & & \\
\hline
\end{tabular}


(continuação)

\begin{tabular}{|c|c|c|c|c|c|c|}
\hline & 2000 & & 1991 & & 1980 & 1970 \\
\hline $\begin{array}{l}\text { Farmácia - } \\
\text { graduação }\end{array}$ & 1030,89 & Artes - graduação & 1237,40 & $\begin{array}{l}\text { Psicologia - } \\
\text { bacharelado }\end{array}$ & 534,25 & \\
\hline $\begin{array}{l}\text { Outros cursos de } \\
\text { graduação }\end{array}$ & 957,22 & $\begin{array}{l}\text { Outros de } \\
\text { Ciências Agrárias - } \\
\text { graduação }\end{array}$ & 1159,88 & $\begin{array}{l}\text { Biblioteconomia - } \\
\text { superior }\end{array}$ & 533,45 & \\
\hline $\begin{array}{l}\text { Psicologia - } \\
\text { graduação }\end{array}$ & 896,32 & $\begin{array}{l}\text { Biblioteconomia - } \\
\text { graduação }\end{array}$ & 1155,48 & $\begin{array}{l}\text { Filosofia - } \\
\text { bacharelado }\end{array}$ & 497,31 & \\
\hline $\begin{array}{l}\text { Outros de Letras e } \\
\text { Artes - graduação }\end{array}$ & 854,18 & $\begin{array}{l}\text { Filosofia - } \\
\text { graduação }\end{array}$ & 1121,67 & Nutrição superior & 482,12 & \\
\hline $\begin{array}{l}\text { Biblioteconomia - } \\
\text { graduação }\end{array}$ & 834,63 & \begin{tabular}{l|} 
Farmácia - \\
graduação
\end{tabular} & 1081,26 & $\begin{array}{l}\text { Geografia - } \\
\text { bacharelado }\end{array}$ & 470,26 & \\
\hline $\begin{array}{l}\text { Matemática - } \\
\text { graduação }\end{array}$ & 801,3 & $\begin{array}{l}\text { Outros de } \\
\text { Ciências Biológicas } \\
\text { e da Saúde - } \\
\text { graduação }\end{array}$ & 978,08 & $\begin{array}{l}\text { Educação física - } \\
\text { superior }\end{array}$ & 470,09 & \\
\hline $\begin{array}{l}\text { Enfermagem - } \\
\text { graduação }\end{array}$ & 790,56 & $\begin{array}{l}\text { Enfermagem - } \\
\text { graduação }\end{array}$ & 973,94 & $\begin{array}{l}\text { Enfermagem - } \\
\text { superior }\end{array}$ & 464,62 & \\
\hline Artes - graduação & 785,39 & $\begin{array}{l}\text { Matemática - } \\
\text { graduação }\end{array}$ & 972,27 & $\begin{array}{l}\text { Serviço social - } \\
\text { superior }\end{array}$ & 461,94 & \\
\hline $\begin{array}{l}\text { Filosofia - } \\
\text { graduação }\end{array}$ & 767,62 & $\begin{array}{l}\text { Serviço Social - } \\
\text { graduação }\end{array}$ & 911,41 & $\begin{array}{l}\text { Biologia - } \\
\text { superior }\end{array}$ & 456,03 & \\
\hline $\begin{array}{l}\text { Outros de Ciências } \\
\text { Biológicas e da } \\
\text { Saúde - graduação }\end{array}$ & 744,25 & $\begin{array}{l}\text { Biologia - } \\
\text { graduação }\end{array}$ & 849,40 & $\begin{array}{l}\text { Belas-artes - } \\
\text { superior }\end{array}$ & 455,85 & \\
\hline $\begin{array}{l}\text { Ciências e Estudos } \\
\text { Sociais - graduação }\end{array}$ & 715,66 & Letras - graduação & 836,55 & $\begin{array}{l}\text { História - } \\
\text { bacharelado }\end{array}$ & 443,23 & \\
\hline $\begin{array}{l}\text { Serviço Social - } \\
\text { graduação }\end{array}$ & 713,96 & $\begin{array}{l}\text { Ciências e } \\
\text { Estudos Sociais - } \\
\text { graduação }\end{array}$ & 806,27 & $\begin{array}{l}\text { Antropologia - } \\
\text { superior }\end{array}$ & 430,08 & \\
\hline $\begin{array}{l}\text { Biologia - } \\
\text { graduação }\end{array}$ & 697,98 & $\begin{array}{l}\text { Educação Física - } \\
\text { graduação }\end{array}$ & 789,54 & $\begin{array}{l}\text { Linguística - } \\
\text { superior }\end{array}$ & 412,50 & \\
\hline $\begin{array}{l}\text { Educação Física - } \\
\text { graduação }\end{array}$ & 694,59 & $\begin{array}{l}\text { Pedagogia - } \\
\text { graduação }\end{array}$ & 771,44 & $\begin{array}{l}\text { Educação - } \\
\text { superior }\end{array}$ & 403,70 & \\
\hline Letras - graduação & 635,25 & $\begin{array}{l}\text { História - } \\
\text { graduação }\end{array}$ & 681,95 & $\begin{array}{l}\text { Ciências - } \\
\text { bacharelado }\end{array}$ & 368,71 & \\
\hline $\begin{array}{l}\text { Teologia - } \\
\text { graduação }\end{array}$ & 605,64 & $\begin{array}{l}\text { Ciências - } \\
\text { graduação }\end{array}$ & 677,61 & $\begin{array}{l}\text { Sacerdote - } \\
\text { superior }\end{array}$ & 351,41 & \\
\hline $\begin{array}{l}\text { História - } \\
\text { graduação }\end{array}$ & 589,66 & $\begin{array}{l}\text { Sem curso } \\
\text { superior }\end{array}$ & 665,48 & $\begin{array}{l}\text { Sem curso } \\
\text { superior }\end{array}$ & 225,95 & \\
\hline $\begin{array}{l}\text { Geografia - } \\
\text { graduação }\end{array}$ & 586,58 & $\begin{array}{l}\text { Geografia - } \\
\text { graduação }\end{array}$ & 639,26 & & & \\
\hline
\end{tabular}


Odaci Luiz Coradini

Titulação escolar, condição de "elite" e posição social

$\mathrm{O}$ artigo tem como objetivo a apresentação de resultados do exame das relações entre titulação universitária, ocupação profissional e posição social no Brasil das últimas décadas. Utilizando como fonte de dados empíricos os microdados dos censos, é confrontada a titulação universitária com os destinos ocupacionais e o rendimento do trabalho principal. Conforme a hipótese geral, como os usos sociais da titulação universitária se inscrevem numa diversidade de mercados e de relações diferenciadas com a estrutura de poder, por um lado ocorre o crescimento da proporção daqueles que têm alguma ocupação de "elite", por outro, a forte polivalência nos usos da titulação universitária resulta também na grande quantidade dos que exercem alguma ocupação com rendimento inferior ao daqueles da categoria ocupacional correspondente ao título. A área de conhecimento tem pouca importância para tanto, ao contrário das possibilidades de usos da titulação em alguma função de comando ou abaixo da respectiva categoria profissional.

Palavras-chave: titulação universitária e mercado profissional; titulação universitária e grupos dirigentes; titulação escolar e posição social.

University titles, "elite" status and social position

The main goal of this paper is to present the results of an examination of the relations between university titles, professional occupation, and social position in Brazil in recent decades. Using 
census micro data as the source for empirical data, University degrees are confronted with occupational positions and with the income of the main job. According to this paper's general hypothesis, since the social uses of university degrees are imbedded in a myriad of markets and differentiated relations with the structure of power, on the one hand the proportion of those who have an "elite" occupation is growing. On the other hand, the strong diversity in the uses of university degrees also results in the large number of people holding an occupation with lower income to that of the occupational category corresponding to that degree. The field of knowledge has little relevance in this case, contrary to the possibilities of using such a title in a position of power or below that respective professional category.

Key words: university title and professional market; university title and ruling groups; university title and social position.

\section{Titulación escolar, condición de} "elite" y posición social

Este artículo tiene como objetivo la presentación de resultados del examen de las relaciones entre titulación universitaria, ocupación profesional y posición social en Brasil en las últimas décadas. Utilizando como fuente de datos empíricos los pequeños datos de los censos, es confrontada la titulación universitaria con los destinos ocupacionales y el rendimiento del trabajo principal. Según la hipótesis general, como los usos sociales de la titulación universitaria se inscriben en una diversidad de mercados y de relaciones diferenciadas con la estructura de poder, por un lado ocurre el crecimiento de la proporción de aquellos que tienen alguna ocupación de "elite", por otro, la fuerte polivalencia en los usos de la titulación universitaria resulta también en la grande cantidad de los que ejercen alguna ocupación con rendimiento inferior al de aquellos de la categoría ocupacional correspondiente al título. El área de conocimiento tiene poca importancia para tanto, al contrario de las posibilidades de usos de la titulación en alguna función de comando o debajo de la respectiva categoría profesional.

Palabras claves: titulación universitaria y mercado profesional; titulación universitaria y grupos dirigentes; titulación y posición social. 